\title{
Isotopic evidence of enhanced carbonate dissolution at a coal mine drainage site in Allegheny County, Pennsylvania, USA
} \author{
Angela Hartsock ${ }^{\mathrm{d}}$, Harry M. Edenborn ${ }^{\mathrm{d}}$ \\ ${ }^{a}$ Department of Geology and Geography, West Virginia University, Morgantown, WV 26506, United States \\ ${ }^{\mathrm{b}}$ National Energy Technology Laboratory, Regional University Alliance, United States \\ ${ }^{\mathrm{c}}$ Department of Geology and Planetary Science, University of Pittsburgh, Pittsburgh, PA 15260, United States \\ ${ }^{\mathrm{d}}$ National Energy Technology Laboratory, U.S. Department of Energy, Pittsburgh, PA 15236, United States
}

Shikha Sharma ${ }^{\mathrm{a}, \mathrm{b}, *}$, Andrea Sack ${ }^{\mathrm{a}, \mathrm{b}}$, James P. Adams ${ }^{\mathrm{a}, \mathrm{b}}$, Dorothy J. Vesper ${ }^{\mathrm{a}, \mathrm{b}}$, Rosemary C. Capo ${ }^{\mathrm{c}, \mathrm{b}}$,

\section{A R T I C L E I N F O}

\section{Article history:}

Received 31 March 2012

Accepted 10 November 2012

Available online 3 December 2012

Editorial handling by A. Kolker

\begin{abstract}
A B S T R A C T
Stable isotopes were used to determine the sources and fate of dissolved inorganic C (DIC) in the circumneutral $\mathrm{pH}$ drainage from an abandoned bituminous coal mine in western Pennsylvania. The $\mathrm{C}$ isotope signatures of DIC $\left(\delta^{13} C_{D I C}\right)$ were intermediate between local carbonate and organic $C$ sources, but were higher than those of contemporaneous Pennsylvanian age groundwaters in the region. This suggests a significant contribution of $\mathrm{C}$ enriched in ${ }^{13} \mathrm{C}$ due to enhanced carbonate dissolution associated with the release of $\mathrm{H}_{2} \mathrm{SO}_{4}$ from pyrite oxidation. The $\mathrm{Sr}$ isotopic signature of the drainage was similar to other regional mine waters associated with the same coal seam and reflected contributions from limestone dissolution and cation exchange with clay minerals. The relatively high $\delta^{34} \mathrm{~S}_{\mathrm{SO} 4}$ and $\delta^{18} \mathrm{O}_{\mathrm{SO} 4}$ isotopic signatures of the mine drainage and the presence of presumptive $\mathrm{SO}_{4}$-reducing bacteria suggest that $\mathrm{SO}_{4}$ reduction activity also contributes $\mathrm{C}$ depleted in ${ }^{13} \mathrm{C}$ isotope to the total DIC pool. With distance downstream from the mine portal, $\mathrm{C}$ isotope signatures in the drainage increased, accompanied by decreased total DIC concentrations and increased $\mathrm{pH}$. These data are consistent with $\mathrm{H}_{2} \mathrm{SO}_{4}$ dissolution of carbonate rocks, enhanced by cation exchange, and $\mathrm{C}$ release to the atmosphere via $\mathrm{CO}_{2}$ outgassing.
\end{abstract}

(C) 2012 Elsevier Ltd. All rights reserved.

\section{Introduction}

Rivers have been estimated to transport $1 \pm 0.2 \mathrm{Gt}$ of $\mathrm{C} / \mathrm{a}$ from terrestrial to marine systems and thus play a major role in the global C cycle (Amiotte Suchet et al., 2003). Rivers can also lose up to $50 \%$ of the total $C$ that they receive from anthropogenic and natural sources by $\mathrm{CO}_{2}$ outgassing to the atmosphere during transport (Cole et al., 2007). Carbon dioxide evasion rates are especially high from tropical and subtropical rivers that have high rates of organic matter degradation (Quay et al., 1989; Richey et al., 2002; Finlay, 2003; Mayorga et al., 2005; Yao et al., 2007). Rivers in northern temperate climates (between $25^{\circ}$ and $50^{\circ} \mathrm{N}$ ) are also estimated to release ca. $0.5 \mathrm{pg}$ of $\mathrm{C}$ to the atmosphere each year as $\mathrm{CO}_{2}$ (Butman and Raymond, 2011). Urban sources of atmospheric acidity (e.g. $\mathrm{HNO}_{3}$ and $\mathrm{H}_{2} \mathrm{SO}_{4}$ ) can result in the enhanced release of older $\mathrm{C}$ sequestered in carbonate rock reservoirs (Cai et al., 2008; Zhang et al., 2009; Zeng and Masiello, 2010). A C budget study of the Mackenzie River system in Canada showed that $62 \%$ of the DIC discharged to the ocean consisted of ancient sedimentary $\mathrm{C}$ from

\footnotetext{
* Corresponding author at: Department of Geology and Geography, West Virginia University, Morgantown, WV 26506, United States. Tel.: +1 3042936717.

E-mail address: shikha.sharma@mail.wvu.edu (S. Sharma).
}

carbonate minerals, and that atmospheric-sourced $\mathrm{C}$ accounted for the remainder (Calmels et al., 2007). Other important sources of acid for the dissolution of carbonate minerals are active and abandoned coal and metal mines, which expose reactive metal sulfides such as pyrite $\left(\mathrm{FeS}_{2}\right)$ and produce $\mathrm{H}_{2} \mathrm{SO}_{4}$.

In contrast to weathering by carbonic acid (e.g. $\mathrm{CaCO}_{3}+\mathrm{H}_{2} \mathrm{O}+$ $\mathrm{CO}_{2} \rightarrow \mathrm{Ca}^{2+}+2 \mathrm{HCO}_{3}^{-} ; \quad \mathrm{CaSiO}_{3}+\mathrm{H}_{2} \mathrm{O}+2 \mathrm{CO}_{2} \rightarrow \mathrm{Ca}^{2+}+2 \mathrm{HCO}_{3}^{-}+$ $\mathrm{SiO}_{2}$ ), weathering of carbonate minerals by $\mathrm{H}_{2} \mathrm{SO}_{4}$ (e.g. $\left.\mathrm{CaCO}_{3}+\mathrm{H}_{2} \mathrm{SO}_{4} \rightarrow \mathrm{Ca}^{2+}+\mathrm{H}_{2} \mathrm{O}+\mathrm{CO}_{2}+\mathrm{SO}_{4}^{2-}\right)$ does not consume contemporary atmospheric $\mathrm{CO}_{2}$ (Lerman et al., 2007). Only half of the DIC released by the weathering of carbonates via $\mathrm{CO}_{2}$-carbonic acid is older $\mathrm{C}$, whereas all of the DIC released by $\mathrm{H}_{2} \mathrm{SO}_{4}$ weathering is older $\mathrm{C}$. Therefore, $\mathrm{H}_{2} \mathrm{SO}_{4}$-induced weathering is expected to result in a higher net release of stored $C$ relative to carbonic-acid driven weathering.

West Virginia and Pennsylvania each have over $3000 \mathrm{~km}$ of streams that are adversely impacted by drainage from abandoned surface and underground coal mines in the northern Appalachian Coalfield (USEPA, 2008). Because the chemical weathering of carbonate minerals can be significantly enhanced due to production of $\mathrm{H}_{2} \mathrm{SO}_{4}$ via pyrite oxidation, coal mine drainage can contain $\mathrm{CO}_{2}$ concentrations well above those predicted based on equilibrium with the atmosphere (Rose and Cravotta, 1998; Cravotta, 2008b; Kirby et al., 2009; Vesper and Smilley, 2010). 
The goal of this study was to test the use of stable isotopes to differentiate the sources of $C$ contributing to the DIC pool in circumneutral $\mathrm{pH}$ water discharging from an abandoned bituminous coal mine in southwestern Pennsylvania. Stable isotope data were used in conjunction with other geochemical information to differentiate between new and older sources of $C$ at this site. In addition, the $C$ isotope signatures of dissolved inorganic $C\left(\delta^{13} C_{D I C}\right)$ were very sensitive to shifts in dissolved $\mathrm{CO}_{2}$ concentrations, corroborating the value of this technique in demonstrating $\mathrm{CO}_{2}$ evasion from freshwater streams and rivers.

\section{Study sites and methods}

\subsection{Site description}

The study site $\left(40^{\circ} 15^{\prime} 22.40^{\prime \prime} \mathrm{N}, 79^{\circ} 47^{\prime} 41.67^{\prime \prime} \mathrm{W}\right)$ is located near Blythedale, PA in Allegheny County, Pennsylvania (Fig. 1). The Ocean \#2 mine operated in the late 19th and early 20th centuries and exploited the Pittsburgh bituminous coal seam (Metzgar, 2003). The mine portals were sealed in the late 1960s to flood the mine and reduce acid formation. Net alkaline mine water currently discharges from drainage pipes beneath the portals at a rate of approximately $0.01 \mathrm{~m}^{3} / \mathrm{s}$. The drainage flows ca. $10 \mathrm{~m}$ before dropping over a $10 \mathrm{~m}$ high waterfall, and then travels ca. $150 \mathrm{~m}$ downstream, where it discharges into the Youghiogheny River. The waterfall is characterized by a large deposit of Fe oxides, which are also deposited along the entire length of the stream leading to the river.

The geology of this site is typical of coal-producing areas in the Appalachian region (Brady et al., 1998). The Pennsylvanian Monongahela Group ( $\approx 290 \mathrm{Ma}$ ) is divided into the Pittsburgh and Uniontown Formations and extends from the base of the Pittsburgh coal seam to the base of the Waynesburg coal (Hornberger et al., 2004). The group is about $119 \mathrm{~m}$ thick and has been interpreted as purely freshwater deposits, dominated by limestones, dolostones, mudstones, shales, siltstones and a few coals (Brady et al., 1998). Rocks in the study area encompass the lower portion of the Monongahela Group (Fig. 1).

\subsection{Samples and methods}

Water samples were collected directly from a pipe beneath the primary mine portal (F000) and 5, 21, 136 and 166 m downstream (sample identifiers F005, F021, F136 and F166, respectively). To evaluate possible seasonal variability due to changes in precipitation and vegetative cover, samples were collected in December 2010, February and July 2011. Water samples were also collected from groundwater wells tapping other Pennsylvanian formations comprised of shales, siltstones, and limestones with interbedded coals (i.e. Conemaugh, Kanawha and Pottsville) as part of another groundwater quality monitoring project in northern West Virginia (Mulder, 2012).

The $\mathrm{pH}$, temperature, specific conductance, and dissolved $\mathrm{O}_{2}$ were measured using a YSI-566MP meter (YSI Inc., Yellow Springs, $\mathrm{OH})$, calibrated with standard buffers and solutions. Field Gran titrations were conducted with a Hach digital titrator (Hach Co., Loveland, $\mathrm{CO}$ ). Dissolved $\mathrm{CO}_{2}$ was measured with a CarboQC carbonation meter (Anton Paar GmbH, Graz, Austria), which uses a multiple volume expansion method (Vesper and Edenborn, 2012). For groundwater sampling, each well was purged following the EPA Code 540/S-95/504 through a hose line (Puls and Barcelona, 1996). Water samples were collected after 2-3 casing volumes were removed at a rate of less than $1 \mathrm{~L} / \mathrm{min}$ using Teflon sampling line connected to the well plumbing. Samples for stable isotopes were collected after all field parameters had been determined. In addition, rock samples from the Pittsburgh Formation

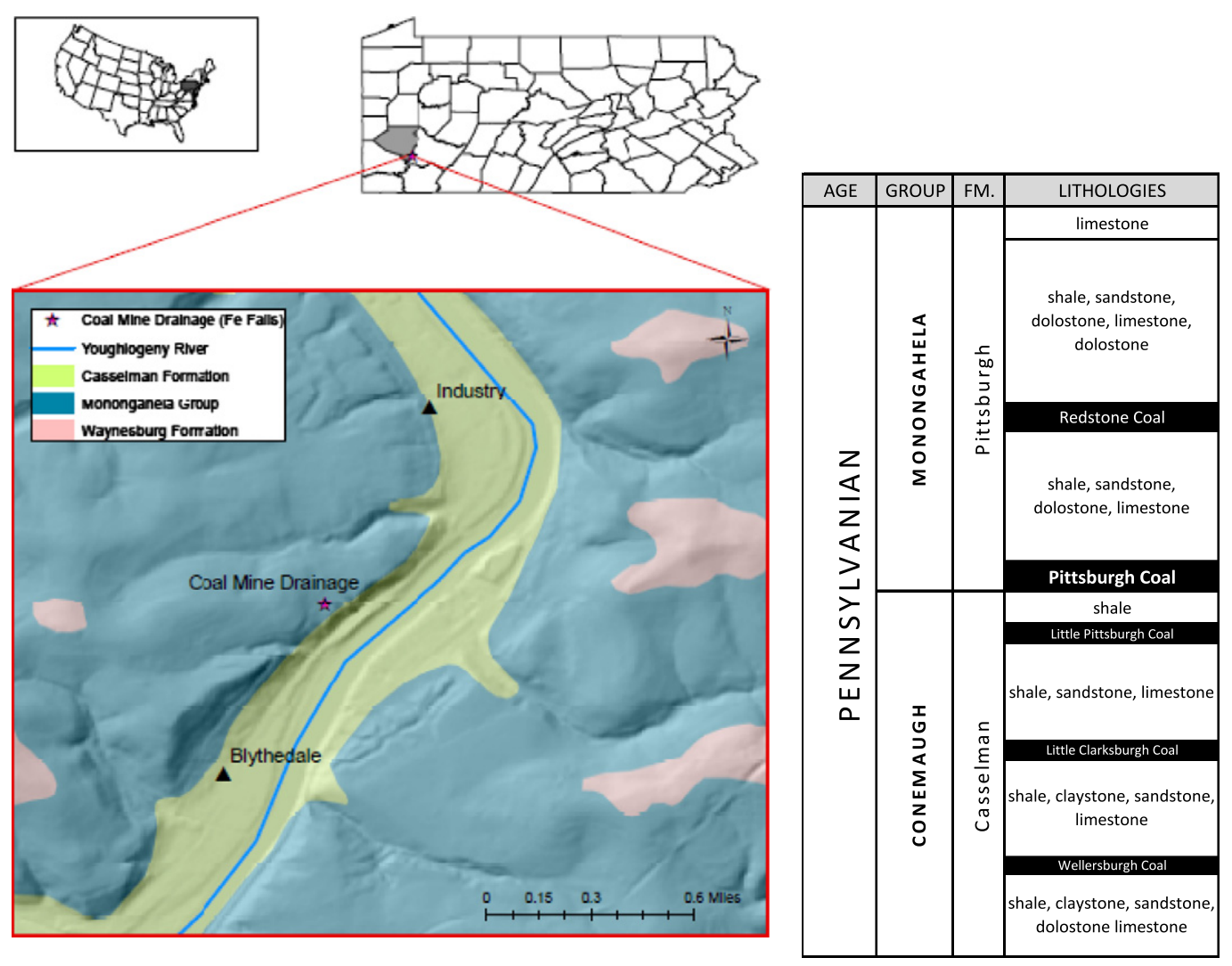

Fig. 1. Location of the coal mine drainage site, geologic map and generalized stratigraphic column. 
at the sampling site were collected, including the Pittsburgh coal plus shale and limestone units above it (Fig. 1). Strontium isotopic analysis was also carried out on Benwood, Fishpot and Redstone limestones and on Pittsburgh coal overburden clay and shale along the eastern limb of the Irwin Syncline near the study area (Capo et al., 2001; Winters and Capo, 2004).

The total concentration of DIC was calculated in MinteqA2 (Allison et al., 1991) based on the total solution composition and the titrated alkalinity measurements. The software determines the aqueous speciation after correcting for temperature and ionic strength. The DIC was calculated as the sum of all carbonate species. This approach may overestimate the DIC by up to $40 \%$ due to the presence of non-carbonate alkalinity that is not fully accounted for in the speciation calculations (Adams, 2012).

Water samples for major cations were passed through a Whatman $45-\mu \mathrm{m}$ filter, collected in a $60 \mathrm{~mL}$ HDPE sample bottle and preserved with $1 \mathrm{~mL}$ of $65 \% \mathrm{HNO}_{3}$. Anion samples were also filtered in the same way and collected in a $30 \mathrm{~mL}$ HDPE sample bottle without acidification. Samples were immediately transported back to the laboratory and refrigerated prior to analysis. Inductively coupled plasma-optical emission spectroscopy (ICP-OES) was used for analysis of major cations and ion chromatography (IC) was used for major anions. For $\delta^{13} C_{\mathrm{DIC}}$, samples were filtered through a $0.45-\mu \mathrm{m}$ PVDF filter and collected in a $10 \mathrm{~mL}$ Wheaton glass serum bottle; a few drops of benzalkonium chloride were then added to prevent biological activity. The bottles were capped with Teflon septa and sealed with crimped Al caps. Samples for $\delta^{34} \mathrm{~S}_{\mathrm{SO} 4}$ were collected in $1 \mathrm{~L}$ HDPE narrow-mouth bottles below the surface of the water and were sealed without headspace. Samples were filtered through a 0.4- $\mu \mathrm{m}$ HTTP Isopore membrane filter in the laboratory. Samples were then treated by acidifying the sample and adding a $20 \%(\mathrm{w} / \mathrm{v}) \mathrm{BaCl}_{2}$ solution. The $\mathrm{BaSO}_{4}$ precipitate was collected on a $0.2-\mu \mathrm{m}$ Isopore PCM filter and dried overnight at $90{ }^{\circ} \mathrm{C}$. The dried precipitate was removed from the filter paper, homogenized and stored prior to analysis (USGS Code 1951, Techniques and Methods 10-C10).

Solid samples for $\mathrm{C}, \mathrm{S}$ and $\mathrm{O}$ isotopic analysis were dried at $50{ }^{\circ} \mathrm{C}$, ground, homogenized and stored for total $\delta^{34} \mathrm{~S}$ and $\delta^{13} \mathrm{C}$ analysis. For organic $\delta^{13} \mathrm{C}$ analysis the samples were treated with $1 \mathrm{~N}$ $\mathrm{HCl}$ and washed 10 times with distilled water before drying.

The $\delta^{13} \mathrm{C}$ of the DIC was measured on a Finnigan Delta Advantage continuous-flow isotope ratio mass spectrometer (CF-IRMS) coupled with a Gasbench Devicein the Stable isotope Laboratory at West Virginia University. The $\delta^{34} S$ and $\delta^{18} \mathrm{O}$ analysis of dissolved sulfate was carried out in the stable isotope laboratory at University of Arizona using an elemental analyzer interfaced to the Finnigan continuous flow mass spectrometer. The reproducibility and accuracy were monitored by duplicate analysis of samples and internal laboratory standards, previously calibrated to international standards, and were better than $0.2 \%$ for $\delta^{13} \mathrm{C}$ and $\delta^{34} \mathrm{~S}$; and $0.4 \%$ for $\delta^{18} \mathrm{O}$. All isotope values are reported in \%o relative to international standards, i.e. $\delta^{13} C_{\text {DIC }}$ relative to VPDB (Vienna Pee Dee Belemnite), $\delta^{34}$ S against VCDT (Vienna Cañon Diablo meteorite), and $\delta^{18} \mathrm{O}$ relative to VSMOW (Vienna Standard Mean Ocean Water).

Strontium isotope preparation and analysis was carried out under clean laboratory conditions at the University of Pittsburgh. Aliquots of mine discharge samples containing approximately $2 \mu \mathrm{g} \mathrm{Sr}$ were evaporated for isotopic analysis. Solid samples were crushed, and limestones were dissolved in ultrapure acetic acid (8\%). To determine the average isotopic composition of $\mathrm{Sr}$ that would be contributed from acidic waters moving through clay-rich overburden rocks, crushed overburden clay and shale were leached with ultrapure $\mathrm{HCl}$ and acetic acid (HOAc). Samples were re-dissolved in $6 \mathrm{~N}$ ultrapure $\mathrm{HNO}_{3}$ and separated for isotopic analysis in Teflon columns using Eichrom ${ }^{\circledR} \mathrm{Sr}$ resin. The total procedural laboratory blank contained $<300 \mathrm{pg}$ Sr. Approximately $500 \mathrm{ng}$ of Sr was evaporated onto a Re filament, and $\mathrm{Sr}$ isotopes of the samples, as well as Sr standard SRM 987 and modern seawater, were measured using a multidynamic method on a Finnigan MAT 262 multicollector thermal ionization mass spectrometer. A total of 100 ratios were measured for each analysis, and interference from ${ }^{87} \mathrm{Rb}$ was monitored by measuring ${ }^{85} \mathrm{Rb}$; instrumental mass fractionation was corrected using ${ }^{86} \mathrm{Sr} /{ }^{88} \mathrm{Sr}=0.1194$. The University of Pittsburgh long-term average ${ }^{87} \mathrm{Sr} /{ }^{86} \mathrm{Sr}$ for the $\mathrm{Sr}$ isotope standard SRM 987 is $0.710242 \pm 0.000017(n=221)$.

Water samples for microbial analysis were collected in sterile bottles and filtered through $150 \mathrm{~mL}$ sterile Nalgene filter units $(0.2 \mu \mathrm{m}, 47 \mathrm{~mm}$ cellulose nitrate filters) in the field. Filters were aseptically transferred to phosphate-buffered $2 \%$ paraformaldehyde (Sigma, St. Louis, MO) and fixed at $4{ }^{\circ} \mathrm{C}$ for $24 \mathrm{~h}$. Sub-samples were filtered onto $0.2 \mu \mathrm{m}, 47 \mathrm{~mm}$ white polycarbonate membranes (Millipore, Isopore) under a vacuum of $127 \mathrm{mmHg}$. Filters were dried and stored at $-20{ }^{\circ} \mathrm{C}$ prior to Fluorescent in situ Hybridization (FISH) analysis (Glockner et al., 1996). FISH was done with domain- and group-specific oligonucleotide DNA probes (IDT, Integrated DNA Technologies) labeled with Cyanine 3 (Glockner et al., 1996). The eubacterial probe mix EUB338-I, -II, -III was used for detection of all Bacteria (Daims et al., 1999). The DELTA495A probe (Loy et al., 2002), applied with its competitor probe (Macalady et al., 2006), was used to detect the Deltaproteobacteria. Probes were applied at $50 \mathrm{ng} / \mu \mathrm{L}$ in $25 \%$ formamide. To block background fluorescence due to non-specific binding between probes and mineral particulates, samples were treated with a pre-hybridization blocking step consisting of a $2 \mathrm{~h}, 46^{\circ} \mathrm{C}$ incubation in hybridization buffer with bovine serum albumin $(0.4 \mathrm{mg} / \mathrm{mL}$ ) (Sigma Chemical Co.; Daims et al., 1999). Samples were counterstained with $10 \mu \mathrm{g} / \mathrm{mL}$ 4',6-diamidino-2-phenylindole (DAPI) (Sigma Chemical Co.) and mounted in 4:1 Citifluor (AF-1, Ted Pella):Vectashield (Vector Laboratories, Burlingame, CA) on glass microscope slides. Cells were viewed using a Leitz Diaplan epifluorescent microscope equipped with a $100 \times$ PL Fluotar objective and filter cubes for DAPI and Cyanine-3 fluorescence.

\section{Results}

The chemical and isotopic data collected during December, February and July are presented in Table 1 along with the calculated DIC concentrations. In December, the dissolved $\mathrm{CO}_{2}$ concentrations showed a decline from $156 \mathrm{mg} / \mathrm{L}$ at the portal (F000) to $11 \mathrm{mg} / \mathrm{L}$ (F166) at the furthest point downstream. The samples from February and July showed a relative decrease of a similar magnitude (Table 1). The $\delta^{13} C_{\text {DIC }}$ values for all three sampling dates showed enrichment in ${ }^{13} \mathrm{C}$ isotope from portal to downstream. In December, $\delta^{13} \mathrm{C}_{\mathrm{DIC}}$ values ranged from $-6.4 \%$ to $0.8 \%$ and in February values ranged from $-9.0 \%$ to $-0.9 \%$. The July $\delta^{13} \mathrm{C}_{\mathrm{DIC}}$ values showed the greatest enrichment in ${ }^{13} \mathrm{C}$ from portal to downstream, ranging from $-10.2 \%$ to $0.6 \%$.

The DIC concentrations showed a consistent decrease downstream from the mine portal, ranging from 72.2 to $25.8 \mathrm{mg} \mathrm{C} / \mathrm{L}$ in December, 75.0 to $32.5 \mathrm{mg} \mathrm{C/L}$ in February, and 98.2 to $30.5 \mathrm{mg}$ $\mathrm{C} / \mathrm{L}$ in July (Table 1 ). The trends for the spatial change in the DIC at the research site are not affected by the likely overestimation of the DIC concentration. Furthermore, the interpretation based on the isotope data, which is based on fractions of the whole, is not impacted by the DIC error. Ongoing research will address this issue quantitatively, but, for this paper, the DIC concentrations were determined from the alkalinity as described above.

The $\delta^{34} \mathrm{~S}_{\mathrm{SO} 4}$ and $\delta^{18} \mathrm{O}_{\mathrm{SO} 4}$ values for the mine waters ranged from $+8.16 \%$ to $+9.66 \%$ VCDT and $+4.0 \%$ to $+8.6 \%$ VSMOW, 
Table 1

Measured field parameters, geochemical and isotopic data on all samples collected from the coal mine discharge site.

\begin{tabular}{|c|c|c|c|c|c|c|c|c|c|c|c|c|c|c|c|}
\hline $\begin{array}{l}\text { Sample } \\
\text { date }\end{array}$ & $\begin{array}{l}\text { Sample } \\
\text { ID }\end{array}$ & $\begin{array}{l}\text { Temp. } \\
\left({ }^{\circ} \mathrm{C}\right)\end{array}$ & $\mathrm{pH}$ & $\begin{array}{l}\text { Alkalinity as } \\
\mathrm{mg} / \mathrm{L} \mathrm{HCO}_{3}^{-}\end{array}$ & $\begin{array}{l}\mathrm{Na} \\
(\mathrm{mg} / \mathrm{L})\end{array}$ & $\begin{array}{l}\mathrm{Ca} \\
(\mathrm{mg} / \mathrm{L})\end{array}$ & $\begin{array}{l}\mathrm{Mg} \\
(\mathrm{mg} / \mathrm{L})\end{array}$ & $\begin{array}{l}\text { Fe } \\
(\mathrm{mg} / \mathrm{L})\end{array}$ & $\begin{array}{l}\mathrm{Cl} \\
(\mathrm{mg} / \mathrm{L})\end{array}$ & $\begin{array}{l}\mathrm{SO}_{4} \\
(\mathrm{mg} / \mathrm{L})\end{array}$ & $\begin{array}{l}\text { DIC } \\
(\mathrm{mg} \mathrm{C} / \mathrm{L})\end{array}$ & $\begin{array}{l}\mathrm{CO}_{2} \\
(\mathrm{mg} \mathrm{CO} / \mathrm{L})\end{array}$ & $\delta^{13} C_{\text {DIC }}$ & $\delta^{34} \mathrm{~S}_{\mathrm{SO} 4}$ & $\delta^{18} \mathrm{O}_{\mathrm{SO} 4}$ \\
\hline \multirow[t]{5}{*}{ 3-December-10 } & F000 & 11.9 & 6.2 & 152 & 85.5 & 94.7 & 35.6 & 17.1 & 108 & 322 & 72.2 & 156 & -6.4 & 8.2 & 4.0 \\
\hline & F005 & 12.2 & 6.5 & 169 & 90.4 & 93.5 & 35.5 & 17.5 & 107 & 328 & 58.8 & 80 & -4.9 & 8.3 & 7.7 \\
\hline & F021 & 10.2 & 7.4 & 144 & 92.8 & 94.0 & 35.6 & 16.2 & 108 & 330 & 31.3 & 14 & -1.1 & 8.4 & 6.9 \\
\hline & F136 & 10.2 & 7.3 & 140 & 96.9 & 94.0 & 35.5 & 6.0 & 107 & 341 & 31.0 & 14 & 0.7 & 8.3 & 5.0 \\
\hline & F166 & 10.1 & 7.5 & 123 & 100 & 103 & 35.9 & 4.6 & 108 & 345 & 25.8 & 11 & 0.8 & 8.3 & 5.5 \\
\hline \multirow[t]{5}{*}{ 12-February-11 } & F000 & 11.5 & 6.3 & 168 & 115 & 96.3 & 37.5 & 19.8 & 152 & 328 & 75.0 & 136 & -9.0 & 8.6 & 4.4 \\
\hline & F005 & 11.4 & 6.6 & 161 & 116 & 99.5 & 38.3 & 19.5 & 153 & 335 & 52.0 & 70 & -6.6 & 8.7 & 4.7 \\
\hline & F021 & 10.8 & 7.1 & 157 & 118 & 97.7 & 38.0 & 12.5 & 151 & 329 & 32.4 & 8 & -2.0 & 8.6 & 4.8 \\
\hline & F136 & 10.1 & 6.9 & 150 & 117 & 98.2 & 38.3 & 7.9 & 149 & 338 & 39.6 & 10 & -1.8 & 8.4 & 4.6 \\
\hline & F166 & 9.9 & 7.2 & 141 & 114 & 95.5 & 37.3 & 6.8 & 152 & 345 & 32.5 & 8 & -0.9 & 8.5 & 4.8 \\
\hline \multirow[t]{5}{*}{ 27-July-11 } & F000 & 13.6 & 6.0 & 146 & 183 & 109 & 44.1 & 66.7 & 160 & 628 & 98.2 & 193 & -10.2 & 9.7 & 5.1 \\
\hline & F005 & 13.2 & 6.2 & 158 & 137 & 104 & 42.3 & 39.2 & 102 & 521 & 80.5 & 134 & -6.6 & - & - \\
\hline & F021 & 13.8 & 6.8 & 131 & 159 & 106 & 42.9 & 41.3 & 129 & 539 & 36.0 & 16 & -1.9 & 9.2 & 4.8 \\
\hline & F136 & 14.4 & 6.7 & 108 & 160 & 114 & 46.0 & 34.2 & 110 & 531 & 29.8 & 27 & -0.6 & 8.9 & 4.8 \\
\hline & F166 & 13.7 & 6.5 & 88 & 156 & 110 & 44.8 & 29.6 & 109 & 528 & 30.5 & 16 & 0.6 & 8.8 & 4.4 \\
\hline
\end{tabular}

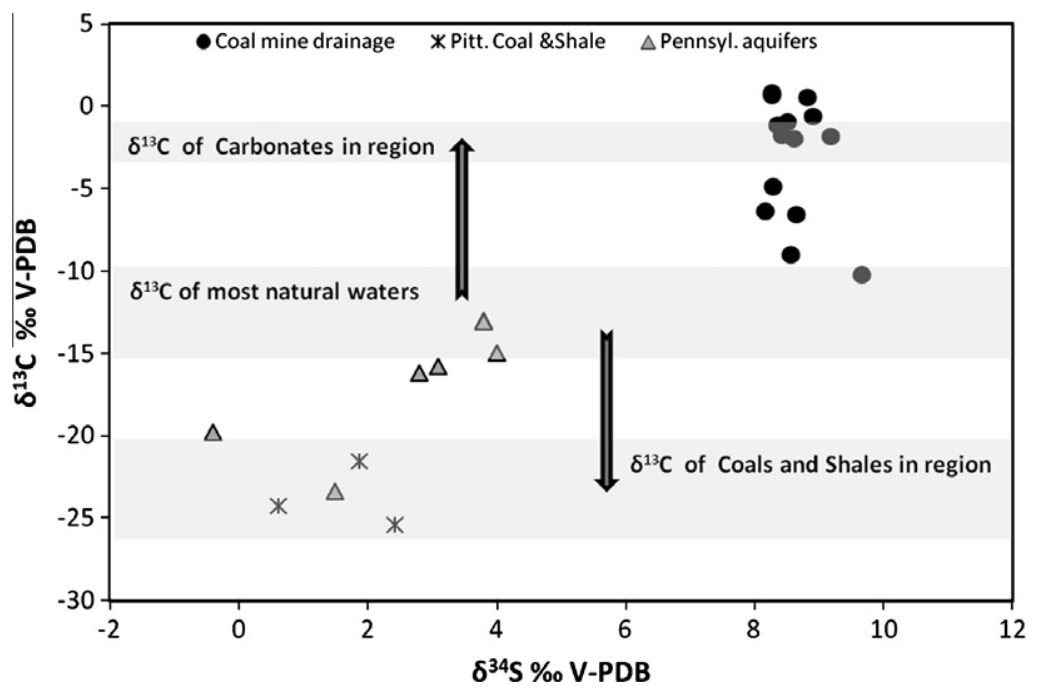

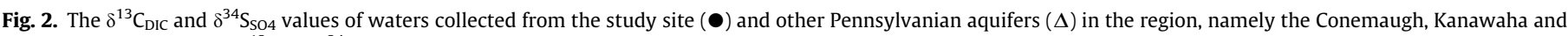

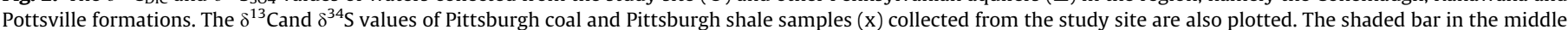

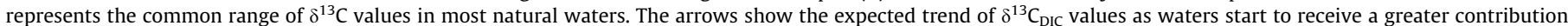

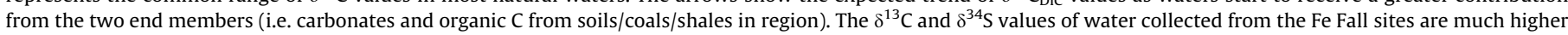
than other groundwaters of the region.

respectively (Table 1 ). The $\delta^{13} \mathrm{C}_{\mathrm{DIC}}$ and $\delta^{34} \mathrm{~S}_{\mathrm{SO} 4}$ signatures of water samples collected from groundwater wells tapping different Pennsylvanian-aged formations away from mine impacted areas (i.e. Conemaugh, Kanawha and Pottsville) in northern West Virginia ranged from $-13 \%$ to $-23 \%$ VPDB and $-0.4 \%$ to $+4.0 \%$ VCDT, respectively (Fig. 2). Although the regional water isotope data presented (Fig. 2) are from different strata and formations than the mine-drainage waters, they are provided as a comparison to the mine-impacted waters. The isotope mixing model used the isotope values obtained from the same rock formations as those that were mined. Pittsburgh coal samples were collected near the study site (Fig. 1); $\delta^{34} \mathrm{~S}$ and $\delta^{13} \mathrm{C}$ values for Little Pittsburgh coal and Pittsburgh shale were $-0.6 \%$, $+2.4 \%$ and $+1.9 \%$ VCDT and $-24.3 \%$, $-25.4 \%$ and $-21.6 \%$ VPDB, respectively. In contrast, the $\delta^{13} \mathrm{C}$ signatures of the two Pittsburgh Formation limestone units above the Pittsburgh coal were $-2.5 \%$ and $-1.7 \%$ VPDB, respectively (Fig. 2).

Strontium isotope results from water samples collected in December 2010, April 2011 and July 2011, and from overburden end members are presented in Table 2 as both ${ }^{87} \mathrm{Sr} /{ }^{86} \mathrm{Sr}$ and epsilon units $\left(\varepsilon_{\mathrm{Sr}}^{\mathrm{SW}}\right)$, where

$\varepsilon_{\mathrm{Sr}}^{\mathrm{SW}}=10^{4}\left(\frac{{ }^{87} \mathrm{Sr} /{ }^{86} \mathrm{Sr}_{\text {sample }}}{{ }^{87} \mathrm{Sr} /{ }^{86} \mathrm{Sr}_{\text {seawater }}}-1\right)$

The measured ${ }^{87} \mathrm{Sr} /{ }^{86} \mathrm{Sr}$ ratio for seawater was 0.709168 . The $\mathrm{Sr}$ isotopic composition of the water samples fell within the range of other coal mine drainage waters in southwestern Pennsylvania that are associated with the Pittsburgh coal $\left({ }^{87} \mathrm{Sr} /{ }^{86} \mathrm{Sr}=0.71168\right.$ $0.71262 ; \varepsilon_{\mathrm{Sr}}^{\mathrm{SW}}=+35.3$ to +48.7 ; Chapman et al., 2012).

Mine portal water contained ca. $6 \times 10^{5}$ cells $/ \mathrm{mL}( \pm 13 \%)$, with approximately $90 \%$ of cells identified as Bacteria by in situ hybridization using nucleic acid probes. Using a more specific probe, a sub-set of these cells was identified as Deltaproteobacteria, a class of bacteria that includes many of the known $\mathrm{SO}_{4}$-reducing bacteria. 
Table 2

Strontium concentration and isotope data for samples collected from the coal mine discharge site and limestone and clay shale end-members.

\begin{tabular}{|c|c|c|c|c|}
\hline Sample date & Sample ID & $\operatorname{Sr}(\mu \mathrm{g} / \mathrm{L})$ & ${ }^{87} \mathrm{Sr} /{ }^{86} \mathrm{Sr}$ & $\varepsilon_{\mathrm{Sr}}$ \\
\hline \multicolumn{5}{|l|}{ Mine waters } \\
\hline \multirow[t]{5}{*}{ 3-December-10 } & F000 & 1695 & $0.712021 \pm 10$ & $40.20 \pm .14$ \\
\hline & F005 & 1714 & $0.712039 \pm 09$ & $40.46 \pm .11$ \\
\hline & F021 & 1706 & $0.712039 \pm 09$ & $40.46 \pm .13$ \\
\hline & F136 & 1684 & $0.712042 \pm 08$ & $40.50 \pm .14$ \\
\hline & F166 & 1686 & $0.712058 \pm 10$ & $40.72 \pm .13$ \\
\hline \multirow[t]{5}{*}{ 10-April-11 } & F000 & 1519 & $0.712056 \pm 10$ & $40.70 \pm .13$ \\
\hline & F005 & 1476 & $0.712066 \pm 08$ & $40.84 \pm .10$ \\
\hline & F021 & 1653 & $0.712053 \pm 09$ & $40.65 \pm .13$ \\
\hline & F136 & 1524 & $0.712059 \pm 10$ & $40.74 \pm .14$ \\
\hline & F166 & 1421 & $0.712050 \pm 09$ & $40.61 \pm .13$ \\
\hline \multirow[t]{4}{*}{ 27-July-11 } & F000 & 1623 & $0.712075 \pm 09$ & $40.96 \pm .13$ \\
\hline & F005 & 1828 & $0.712098 \pm 07$ & $41.29 \pm .10$ \\
\hline & F136 & 1821 & $0.712100 \pm 10$ & $41.32 \pm .14$ \\
\hline & F166 & 1767 & $0.712082 \pm 11$ & $41.06 \pm .16$ \\
\hline \multicolumn{5}{|c|}{ Limestone end members } \\
\hline \multicolumn{2}{|c|}{ Benwood nodular shale } & \multicolumn{2}{|c|}{$0.711511 \pm 20$} & $33.01 \pm .28$ \\
\hline \multicolumn{2}{|c|}{ Benwood - dolomitic } & \multicolumn{2}{|c|}{$0.711320 \pm 11$} & $30.32 \pm .16$ \\
\hline \multicolumn{2}{|c|}{ Benwood limestone } & \multicolumn{2}{|c|}{$0.711081 \pm 11$} & $26.95 \pm .16$ \\
\hline \multicolumn{2}{|c|}{ Fishpot limestone4 } & \multicolumn{2}{|c|}{$0.711076 \pm 10$} & $26.88 \pm .14$ \\
\hline \multicolumn{2}{|c|}{ Fishpot limestone6 } & \multicolumn{2}{|c|}{$0.710675 \pm 11$} & $21.22 \pm .16$ \\
\hline \multicolumn{2}{|c|}{ Redstone limestone } & \multicolumn{2}{|c|}{$0.710673 \pm 15$} & $21.19 \pm .21$ \\
\hline \multicolumn{2}{|c|}{ AVG. } & \multicolumn{2}{|c|}{0.711100} & 26.59 \\
\hline \multicolumn{5}{|c|}{ Clay-shale end members (Pittsburgh coal overburden acid leachates) } \\
\hline \multicolumn{2}{|c|}{ GUC3-HCl } & \multicolumn{2}{|c|}{$0.717373 \pm 60$} & $115.70 \pm .08$ \\
\hline \multicolumn{2}{|l|}{ GUC3-HOAc } & \multicolumn{2}{|c|}{$0.715758 \pm 10$} & $92.90 \pm .14$ \\
\hline \multicolumn{2}{|l|}{ GUC3-HOAc-HCl } & \multicolumn{2}{|c|}{$0.726856 \pm 70$} & $249.40 \pm .10$ \\
\hline \multicolumn{2}{|l|}{$\mathrm{GCP}-\mathrm{HCl}$} & \multicolumn{2}{|c|}{$0.721528 \pm 10$} & $174.30 \pm .14$ \\
\hline \multicolumn{2}{|l|}{ GCP-HOAC } & \multicolumn{2}{|c|}{$0.729778 \pm 11$} & $290.60 \pm .16$ \\
\hline \multicolumn{2}{|l|}{$\mathrm{GCP}-\mathrm{HOAC}-\mathrm{HCl}$} & 0.7181 & \pm 11 & $126.20 \pm .16$ \\
\hline AVG. & & 0.7216 & & 174.80 \\
\hline
\end{tabular}

\section{Discussion}

\subsection{Isotopic indicators of sources of carbon}

To understand sources of $C$ in the DIC of the studied mine discharge, water samples collected directly from the mine portal were used. The samples collected downstream were not used because after the water is discharged from the portal, $C$ exchange occurs in a dynamic open system environment where kinetic isotopic fractionation processes dominate and become difficult to model. Also, in the interpretation of mine portal data, it is important to remember that these values represent the contribution of different reactions occurring throughout the entire mine system that may be variable seasonally. Flooded areas of the abandoned mine are liable to become seasonally exposed to air and contribute greater acidity due to enhanced pyrite oxidation. The hydrology of the extensive abandoned coal mine operations is not well understood, so that the contribution of both aerobic and anaerobic processes, in addition to periodic short-circuiting of surface waters to the mine pool, are to be expected.

\subsubsection{Carbon isotopes}

The two primary sources of DIC in natural waters are $\mathrm{CO}_{2}$ derived from decaying organic matter and carbonate rock dissolution, with the contribution of atmospheric $\mathrm{CO}_{2}$ being negligible (Mook and Tan, 1991; Clark and Fritz, 1997). The average $C$ isotope signatures of the two contributing end members, soil $\mathrm{CO}_{2}$ and carbonates, are very distinct. The average $\delta^{13} \mathrm{C}$ of soil $\mathrm{CO}_{2}$ in $\mathrm{C} 3$-plantdominated temperate areas like the study site is expected to be approximately $-23 \%$ VPDB (Aravena et al., 1992). On the other hand, the $\delta^{13} \mathrm{C}$ of most carbonate rocks is around $0 \pm 2 \%$. Most groundwaters receiving equal contributions from both these end members have $\delta^{13} \mathrm{C}_{\text {DIC }}$ ranging between $-11 \%$ o to $-16 \%$ (Mook and Tan, 1991).

Microbial processes occurring within the mine would be anticipated to affect the composition of stable $\mathrm{C}$ isotopes in the mine water in predictable ways. Active biogenic methanogenesis in highly-reducing anaerobic conditions can result in very enriched $\delta^{13} \mathrm{C}_{\mathrm{DIC}}$ signatures in the range of $+10 \%$ to $+30 \%$ due to the preferential removal of 12-C (Simpkins and Parkin, 1993; Scott et al. 1994; Botz et al., 1996; Martini et al., 1998; Whiticar, 1999; Hellings et al., 2000; Aravena et al., 2003; McIntosh et al., 2008; Sharma and Frost, 2008; McLaughlin et al., 2011; Sharma and Baggett, 2011). In contrast, the oxidation of $\mathrm{CH}_{4}$ can result in highly-depleted $\delta^{13} \mathrm{C}_{\mathrm{DIC}}$ signatures, generally lower than $-30 \%$ (Holland and Turekian, 2011). However, in abandoned coal mines like the study site, where $\mathrm{SO}_{4}^{2-}$ is an abundant soluble anion, bacterial $\mathrm{SO}_{4}$ reduction is the more likely predominant anaerobic microbial process (Whiticar, 1999). This activity, through its action on labile organic compounds derived from soil, would deplete the ${ }^{13} \mathrm{C}$ fraction of the total DIC. The $\mathrm{C}$ isotope value of total organic $\mathrm{C}$ of the soil organic matter in the study area is about $-23 \%$. Bituminous coal itself can be considered an unlikely source of labile $C$ for bacteria in general (Ehrlich and Newman, 2009), although more labile sources of organic material, such as mine timbers and other organic detritus, may continue to supply dissolved organic matter that can be oxidized by bacteria.

In the $\mathrm{pH}$ range of the mine portal waters (ca. 6.0-6.3), $\mathrm{CO}_{2}(\mathrm{aq})$ and $\mathrm{HCO}_{3}^{-}$are the dominant inorganic $\mathrm{C}$ species, and, therefore, the isotopic fractionations between the $\mathrm{CO}_{2}$ gas going into solution and dissociating into $\mathrm{CO}_{2}(\mathrm{aq})$ and $\mathrm{HCO}_{3}^{-}$, should be the primary controls on the $\mathrm{C}$ isotopic composition of total DIC. If it is presumed that the sole source of $\mathrm{C}$ in the mine pool is $\mathrm{CO}_{2}$ gas produced by oxidation of organic matter from soil (average value approximately $-23 \%$ ) and that complete equilibrium is reached, the $\delta^{13} \mathrm{C}$ of the DIC can be modeled from the concentrations of $\mathrm{CO}_{2}(\mathrm{aq}), \mathrm{HCO}_{3}^{-}$ and $\mathrm{CO}_{3}^{2-}$, and the temperature-dependent equilibrium isotopic fractionation factors, using the following equation:

$$
\begin{aligned}
& \delta^{13} \mathrm{C}_{\mathrm{DIC}}\left(m \mathrm{CO}_{2(\mathrm{aq})}+m \mathrm{HCO}_{3}^{-}+m \mathrm{CO}_{3}^{2-}\right) \\
&=m \mathrm{CO}_{2(\mathrm{aq})}\left(\delta^{13} \mathrm{C}_{\mathrm{CO} 2(\mathrm{~g})}+\varepsilon^{13} \mathrm{C}_{\mathrm{CO} 2(\mathrm{aq})-\mathrm{CO} 2(\mathrm{~g})}\right) \\
&+ m \mathrm{HCO}_{3}^{-}\left(\delta^{13} \mathrm{C}_{\mathrm{CO} 2(\mathrm{~g})}+\varepsilon^{13} \mathrm{C}_{\mathrm{HCO} 3-\mathrm{CO} 2(\mathrm{~g})}\right) \\
&+m \mathrm{CO}_{3}^{2-}\left(\delta^{13} \mathrm{C}_{\mathrm{CO} 2(\mathrm{~g})}+\varepsilon^{13} \mathrm{C}_{\mathrm{CO} 3-\mathrm{CO} 2(\mathrm{~g})}\right)
\end{aligned}
$$

where the concentrations of each species $\left(\mathrm{mCO}_{2}, \quad m \mathrm{HCO}_{3}^{-}\right.$, and $\mathrm{mCO}_{3}^{2-}$ ) are expressed in $\mathrm{mol} / \mathrm{L}$. The isotopic enrichment, $\varepsilon$, between each species is temperature-dependent and is taken to be approximately equal to 1000 times the natural log of the isotopic fractionation factor $(\alpha)$, calculated using the equation $10^{3} \ln \alpha=a\left(10^{6} / T_{k}^{2}\right)+b\left(10^{3} / T_{k}\right)+c$, where $a, b$, and $c$ are constants and temperature is in Kelvin. The isotopic fractionation factors

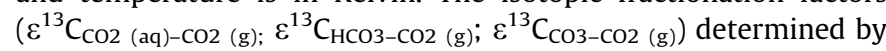
Mook et al. (1974) and Deines et al. (1974) were used for this calculation. Taking the well-defined equilibrium fractionation into account, the modeled $\delta^{13} \mathrm{C}_{\text {DIC }}$ of portal waters are $-21.6 \%$, $-21.0 \%$ and $-22.0 \%$ VPDB in December, February and July, respectively (Table 3). However, the measured $\delta^{13} \mathrm{C}_{\text {DIC }}$ values of portal water were $-6.4 \%$ in December, $-9.0 \%$ in February and $-10.2 \%$ in July, which were much more enriched in ${ }^{13} \mathrm{C}$ than expected if the $\mathrm{C}$ added to DIC primarily originated from the oxidation of organic matter (Table 1).

Another potential contributor to the pool of DIC is the $\mathrm{HCO}_{3}^{-}$ that originates from the dissolution of carbonates by dissolved $\mathrm{CO}_{2}$, and/or by $\mathrm{H}_{2} \mathrm{SO}_{4}$ produced as a by-product of pyrite oxidation in coal mines, via the following reactions:

$\mathrm{CO}_{2}+\mathrm{H}_{2} \mathrm{O}+\mathrm{CaCO}_{3} \rightarrow 2 \mathrm{HCO}_{3}^{-}+\mathrm{Ca}^{2+}$ 
Table 3

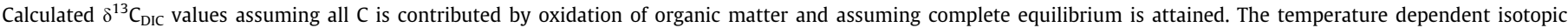
enrichment factor was calculated using the constant determined by Mook et al. (1974) and Deines et al. (1974).

\begin{tabular}{|c|c|c|c|c|c|c|c|}
\hline Sample ID & $m \mathrm{CO}_{2(\mathrm{aq})}$ & $m \mathrm{HCO}_{3}^{-}$ & $\mathrm{mCO}_{3}^{2-}$ & $\varepsilon^{13} \mathrm{C}_{\mathrm{CO} 2(\mathrm{aq})-\mathrm{CO} 2(\mathrm{~g})}$ & $\varepsilon^{13} \mathrm{C}_{\mathrm{HCO}-\mathrm{CO} 2(\mathrm{~g})}$ & $\varepsilon^{13} \mathrm{C}_{\mathrm{CO} 3-\mathrm{CO} 2(\mathrm{~g})}$ & Cal. $\delta^{13} C_{\text {DIC }}$ \\
\hline F000-December & $3.55 \mathrm{E}-03$ & $2.50 \mathrm{E}-03$ & $1.55 \mathrm{E}-07$ & -1.12 & 8.1 & 6.5 & -21.61 \\
\hline F000-February & $3.09 \mathrm{E}-03$ & $2.76 \mathrm{E}-03$ & $1.91 \mathrm{E}-07$ & -1.12 & 8.2 & 6.5 & -21.02 \\
\hline F000-July & $4.39 \mathrm{E}-03$ & $2.40 \mathrm{E}-03$ & $8.48 \mathrm{E}-08$ & -1.11 & 7.9 & 6.4 & -22.22 \\
\hline
\end{tabular}

$\mathrm{H}_{2} \mathrm{SO}_{4}+2 \mathrm{CaCO}_{3} \rightarrow \mathrm{SO}_{4}^{2-}+2 \mathrm{HCO}_{3}^{-}+2 \mathrm{Ca}^{2+}$

The two reactions may yield different isotopic compositions. In reaction (2a), the isotopic composition of $\mathrm{HCO}_{3}^{-}$will depend on both contributing end-members, i.e., $\mathrm{CO}_{2}$ and $\mathrm{CaCO}_{3}$. On the other hand, in reaction (2b) the isotopic composition of $\mathrm{HCO}_{3}^{-}$will primarily be dependent on the isotopic composition of $\mathrm{CaCO}_{3}$. The measured $\delta^{13} \mathrm{C}$ value of the limestone from the Upper Pittsburgh Formation at the study site was $-2.5 \%$ VPBD. Hence, any contribution from the dissolution of this or similar carbonate units to the total $\mathrm{HCO}_{3}^{-}$pool would increase the total $\delta^{13} \mathrm{C}_{\mathrm{DIC}}$ value in the water (Fig. 2). If it can be assumed that the $\mathrm{C}$ is being contributed by both oxidation of organic $\mathrm{C}$ and carbonate dissolution, a simple two endmember mixing model can be used to calculate the fraction of $\mathrm{C}$ being contributed by the two pools:

$\delta^{13} \mathrm{C}_{\text {mix }}=\delta^{13} \mathrm{C}_{\text {carbonate }} f_{1}+\delta^{13} \mathrm{C}_{\text {organic }}\left(1-f_{1}\right)$

where $\delta^{13} \mathrm{C}_{\text {mix }}$ is the isotopic signature of the DIC in the water sample, $\delta^{13} C_{\text {carbonate }}(-2.5 \%)$ is the isotopic composition of the limestone, $\delta^{13} C_{\text {organic }}(-24.3 \%)$ is the average isotopic composition of the organic matter, and $f_{1}$ is the fractional contribution from carbonate dissolution. Using this simple two end-member mixing model, it appears that carbonate dissolution is the dominant source of $\mathrm{C}$ to the total DIC. The percent contribution of carbonate dissolution varied seasonally. The contribution from carbonate dissolution ranges from approximately $82 \%$ in December, $70 \%$ in February and to $65 \%$ in July (Fig. 3). However, this mixing model does not account for variations in total DIC speciation or contributions from groundwater recharge or snowmelt. The higher $\delta^{13} C_{\text {DIC }}$ values of portal water in December can be ascribed to a higher fractional contribution of $\mathrm{HCO}_{3}^{-}$isotopically-enriched in ${ }^{13} \mathrm{C}$ derived from carbonate dissolution to the total DIC pool. The $\delta^{13} C_{\text {DIC }}$ values of samples collected at the study site were much higher than those in groundwater aquifers not connected to the coal mines of the region (Mulder, 2012). The higher $\delta^{13} C_{\text {DIC }}$ values in mine water compared to other Pennsylvanian-aged aquifers further supports the hypothesis that waters discharging from this portal have received a significant con-

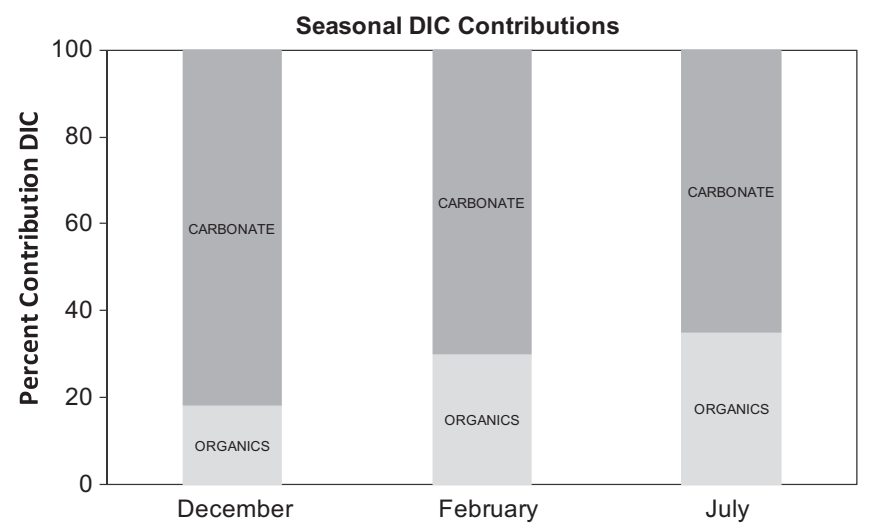

Fig. 3. Variations in contribution of $C$ from organic matter oxidation and carbonate dissolution to the total DIC pool. The contributions were calculated using a simple two end-member isotope mixing model. tribution from dissolution of carbonates along their flow path (Fig. 2).

Dissolved Ca concentrations serve as additional indicators of enhanced carbonate mineral dissolution in these abandoned coal mine waters. If limestone dissolution is the primary source of $\mathrm{C}$ to the system, the increase in $\delta^{13} C_{\text {DIC }}$ signatures should be accompanied by an increase in $\mathrm{Ca}^{2+}$ and $\mathrm{HCO}_{3}^{-}$concentrations. However, $\delta^{13} C_{\text {DIC }}$ signatures show negative correlation with $\mathrm{Ca}^{2+}$ concentrations (i.e. as $\delta^{13} \mathrm{C}_{\mathrm{DIC}}$ becomes more depleted in ${ }^{13} \mathrm{C}$, the $\mathrm{Ca}^{2+}$ concentrations increase) and no relation with $\mathrm{HCO}_{3}^{-}$concentrations (Fig. 4). The data suggest that additional sources of Ca could be associated with enhanced mineral weathering during summer (see Section 4.1.2).

\subsubsection{Sulfur and oxygen isotopes}

The $\delta^{34} \mathrm{~S}$ and $\delta^{18} \mathrm{O}$ signatures of dissolved $\mathrm{SO}_{4}\left({ }^{34} \mathrm{~S}_{\mathrm{SO}} 4\right.$ and $\left.\delta^{18} \mathrm{O}_{\mathrm{SO} 4}\right)$ can be used to better understand the possible contribution of bacterial $\mathrm{SO}_{4}$ reduction to mine water chemistry. The major factors that control the isotopic composition of $\mathrm{S}$ include the isotopic composition of the sources, fractionation during sulfide oxidation, bacterial $\mathrm{SO}_{4}$ reduction, and isotopic exchange. The isotopic composition of $\mathrm{O}$ in $\mathrm{SO}_{4}$ is more complicated, as both $\mathrm{O}$ in the atmosphere and water can contribute to $\delta^{18} \mathrm{O}_{\text {so4 }}$. The proportion of the contribution from two end-members depends on the reaction pathway and saturation conditions (Taylor et al., 1984; Van Everdingen and Krouse, 1985; Toran and Harris, 1989; Seal, 2003). Biological processes fractionate both the $S$ and $O$ isotope composition of $\mathrm{SO}_{4}$. Therefore, both isotopes have been used in combination in several studies to identify the occurrence of biological processes (Van Donkelaar et al., 1995; Clark and Fritz, 1997; Krouse and Mayer, 2000; Gammons et al., 2010).

The coals (Pittsburgh and Little Pittsburgh) and shales (Pittsburgh) at the study site contain pyrite and their $\mathrm{S}$ isotope values are in the range of $+0.6 \%$ to $+2.4 \%$ VCDT. The dissolved $\mathrm{SO}_{4}$ in the coal mine waters may be produced via the oxidation of pyrite in these coals and shales via the following reactions:

$\mathrm{FeS}_{2}+7 / 2 \mathrm{O}_{2}+\mathrm{H}_{2} \mathrm{O} \rightarrow \mathrm{Fe}^{2+}+2 \mathrm{SO}_{4}^{2-}+2 \mathrm{H}^{+}$

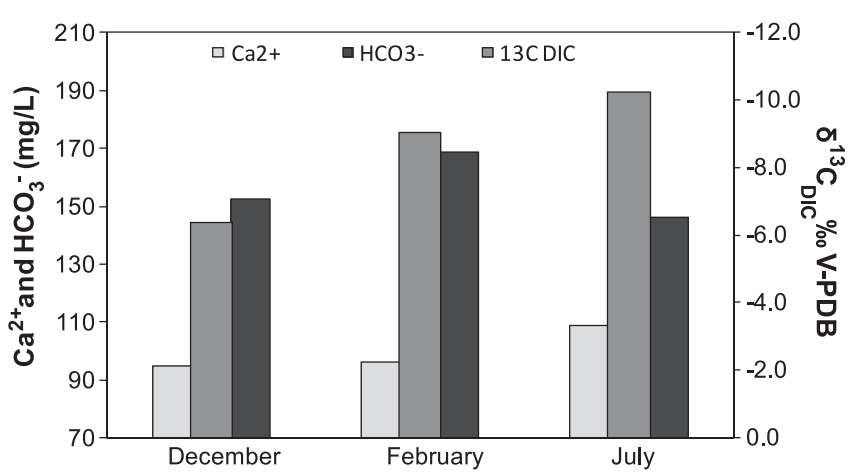

Fig. 4. Variations in $\mathrm{Ca}, \mathrm{HCO}_{3}$ concentrations and $\delta^{13} \mathrm{C}_{\mathrm{DIC}}$ values of samples collected from the mine portal. Note that increase in $\mathrm{Ca}$ concentration is accompanied by a decline in $\delta^{13} C_{\text {DIC }}$ values. 
$\mathrm{FeS}_{2}+14 \mathrm{Fe}^{3+}+8 \mathrm{H}_{2} \mathrm{O} \rightarrow 15 \mathrm{Fe}^{2+}+2 \mathrm{SO}_{4}^{2-}+16 \mathrm{H}^{+}$

The $\delta^{34} \mathrm{~S}_{\mathrm{SO} 4}$ in most cases is similar to the original S source as there is minimal isotopic fractionation involved during the oxidation of dissolved sulfide (Toran and Harris, 1989; Clark and Fritz, 1997; Seal, 2003). The $\delta^{34} \mathrm{~S}_{\mathrm{SO} 4}$ values in groundwater samples collected from Pennsylvanian age aquifers of the region ranged from $-0.4 \%$ o to $+4.0 \%$ VCDT, which is close to the $S$ isotope values of the coals and shales of the area (Fig. 2). However, the isotopic values of $\delta^{34} \mathrm{~S}_{\mathrm{SO} 4}$ in the coal mine water samples were much higher, ranging from $+8.0 \%$ to $+9.7 \%$ VCDT (Fig. 2). Seal and Cravotta (2006) reported very similar findings for other coal mine drainage from this area.

Higher $\delta^{34} \mathrm{~S}_{\mathrm{SO} 4}$ signatures in these waters may be the result of bacterial $\mathrm{SO}_{4}$ reduction occurring within anaerobic regions of the mine:

$2 \mathrm{CH}_{2} \mathrm{O}+\mathrm{SO}_{4}^{2-} \rightarrow 2 \mathrm{HCO}_{3}^{-}+\mathrm{H}_{2} \mathrm{~S}$

where $\mathrm{CH}_{2} \mathrm{O}$ represents labile organic compounds that can serve as bacterial substrates. Mine discharge characteristics, including high $\mathrm{SO}_{4}^{2-}$ concentrations, circumneutral $\mathrm{pH}$, constant cool temperatures and the presence of $\mathrm{SO}_{4}$-reducing bacteria, are all consistent with the potential for $\mathrm{SO}_{4}$ reduction activity within the mine. Sulfatereducing bacteria preferentially remove the lighter isotope of both $\mathrm{S}\left({ }^{32} \mathrm{~S}\right)$ and $\mathrm{O}\left({ }^{16} \mathrm{O}\right)$, leaving the residual $\mathrm{SO}_{4}^{2-}$ pool enriched in both ${ }^{34} \mathrm{~S}$ and ${ }^{18} \mathrm{O}$ over time. The $\mathrm{HCO}_{3}^{-}$in this reaction further originates from organic $C$ sources which are relatively depleted in ${ }^{13} \mathrm{C}$. Thus, if the fraction of DIC contributed by this process is large, bacterial $\mathrm{SO}_{4}$ reduction can produce low values of $\delta^{13} \mathrm{C}_{\text {DIC. }}$.

The isotopic enrichment observed in the $\mathrm{SO}_{4}^{2-}$ pool can vary from $4 \%$ o to $46 \%$ depending on the bacterial species involved, the supply of $\mathrm{SO}_{4}$, the rate of $\mathrm{SO}_{4}$ reduction, temperature and $\mathrm{pH}$ (Kemp and Thode, 1968; Fritz et al., 1989; Clark and Fritz, 1997). The enrichment of ${ }^{18} \mathrm{O}$ during bacterial $\mathrm{SO}_{4}$ reduction is $2.5-4$ times less than that of ${ }^{34} \mathrm{~S}$, but the enrichment increases throughout the reaction until it plateaus (Fritz et al., 1989; Pierre, 1989). All of the water samples collected at this site showed higher $\delta^{34} \mathrm{~S}_{\mathrm{SO} 4}$ and $\delta^{18} \mathrm{O}_{\mathrm{SO} 4}$ signatures compared to other groundwaters of the region (Fig. 5). This suggests that waters discharging from the mine portal may have undergone bacterial $\mathrm{SO}_{4}$ reduction somewhere along their flow path. Alternatively, enrichment in ${ }^{18} \mathrm{O}$ can also result from oxidation of intermediate sulfoxyanions during the formation of aqueous $\mathrm{SO}_{4}$ under $\mathrm{O}_{2}$-limited conditions (Seal, 2003; Seal and Cravotta, 2006). If that is the case, then enrichment of $\delta^{18} \mathrm{O}_{\mathrm{SO} 4}$ may not be related to $\mathrm{SO}_{4}$ reduction. However, the presence of potential $\mathrm{SO}_{4}$-reducing bacteria, accompanied by an enrichment of $\delta^{34} \mathrm{~S}_{\mathrm{SO} 4}$, argues for $\mathrm{SO}_{4}$ reduction as a reasonable explanation.

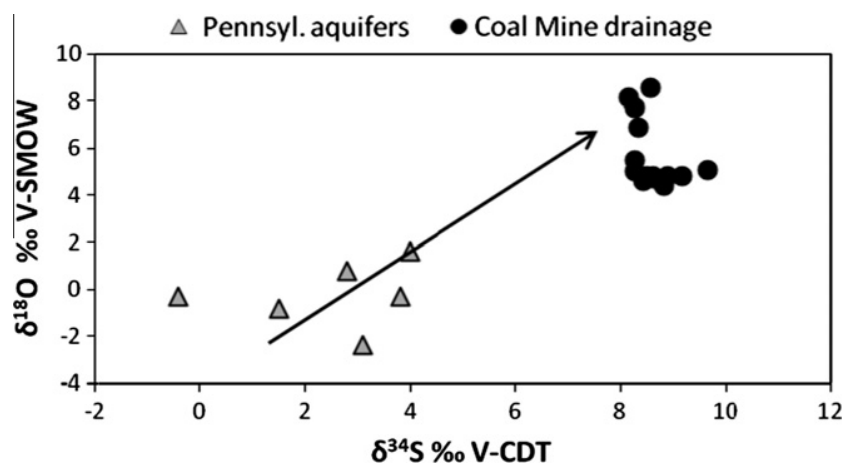

Fig. 5. Comparison between $\delta^{34} \mathrm{~S}_{\mathrm{SO} 4}$ and $\delta^{18} \mathrm{O}_{\mathrm{SO} 4}$ of groundwaters from other different Pennsylvanian aged formations (Conemaugh, Kanawaha and Pottsville) and waters collected from coal mine discharge site.

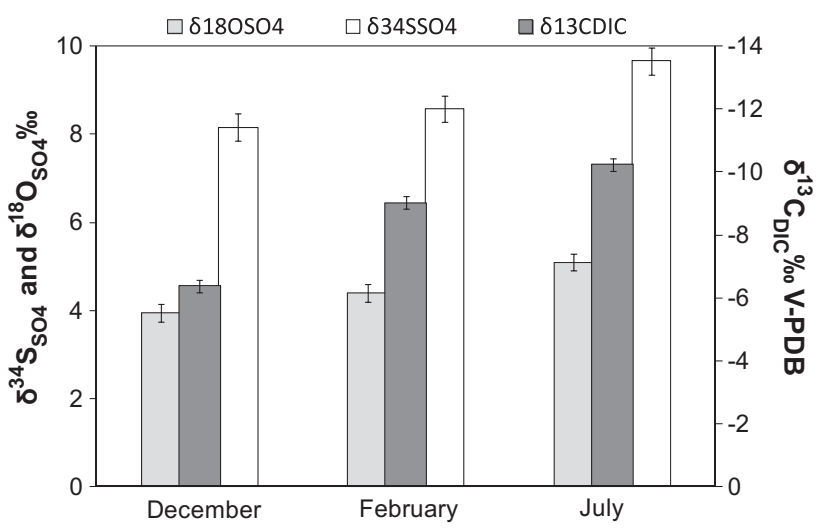

Fig. 6. Variations in $\delta^{34} \mathrm{~S}_{\mathrm{SO} 4}$ and $\delta^{18} \mathrm{O}_{\mathrm{SO} 4}$ to $\delta^{13} \mathrm{C}_{\mathrm{DIC}}$ of samples collected from the mine portal. The increase in $\delta^{34} \mathrm{~S}_{\mathrm{SO} 4}$ and $\delta^{18} \mathrm{O}_{\mathrm{SO} 4}$ from December to July is associated with a decline in $\delta^{13} C_{\text {DIC. }}$.

Isotopic variations in samples collected from the mine relative to seasonal variations in $C$ sources were also examined. The sample collected in July showed the highest $\delta^{34} \mathrm{~S}_{\mathrm{SO} 4}(+9.66 \%$ VCDT) and $\delta^{18} \mathrm{O}_{\mathrm{SO} 4}(+5.1 \%$ V VMOW $)$, accompanied by the lowest $\delta^{13} \mathrm{C}_{\mathrm{DIC}}$ value (-10.2\%o VPDB) (Fig. 6). This most likely indicates that there is an increase in the fractional contribution of isotopically lighter soil organic $C$ to the DIC during the summer due to enhanced biological productivity. Likewise, higher amount of organics could stimulate bacterial $\mathrm{SO}_{4}$ reduction in certain portions of the mine pool. However, if bacterial $\mathrm{SO}_{4}$ reduction activity were significantly enhanced, a decline in $\mathrm{SO}_{4}$ concentrations in July would be anticipated (Eq. (5)). In contrast, there was an increase in observed $\mathrm{SO}_{4}$ and $\mathrm{Fe}$ concentrations between December and July (322$628 \mathrm{mg} / \mathrm{L}$ and $17-66 \mathrm{mg} / \mathrm{L}$, respectively). The increased $\mathrm{SO}_{4}$ concentration in summer could be due to rapid dissolution of secondary $\mathrm{SO}_{4}$-bearing minerals, such as coquimbite $\left(\mathrm{Fe}_{2}^{3+}\left(\mathrm{SO}_{4}\right)_{3}\right.$. $\left.9 \mathrm{H}_{2} \mathrm{O}\right)$, pickeringite $\left(\mathrm{MgAl}_{2}\left(\mathrm{SO}_{4}\right)_{4} \cdot 22 \mathrm{H}_{2} \mathrm{O}\right)$, and roemerite $\left(\mathrm{Fe}^{2+} \mathrm{Fe}_{2}^{3+}\left(\mathrm{SO}_{4}\right)_{4} \cdot 14 \mathrm{H}_{2} \mathrm{O}\right)$, which have been reported to form by the oxidation of pyrite in Pennsylvania coals and overburden shale during periods of low rainfall (Cravotta, 1994). During large precipitation events, these minerals may be dissolved by recharge or rising groundwater, releasing dissolved $\mathrm{SO}_{4}$ and associated cations into the groundwater within the mine (Cravotta, 1994; Brady et al., 1998). Additional evidence for this weathering hypothesis is reflected in the observed increases in $\mathrm{Mg}$ concentrations (Table 1).

\subsection{Isotopic indicators of $\mathrm{CO}_{2}$ outgassing}

The $C$ released via carbonate dissolution and/or organic matter oxidation contributes to total DIC concentration. Total DIC is equal to the sum of the three main species $\left[\mathrm{CO}_{2}(\mathrm{aq})\right]+\left[\mathrm{HCO}_{3}^{-}\right]+\left[\mathrm{CO}_{3}^{2-}\right]$. The different DIC species have different isotopic compositions and the specific isotope fractionation factors are well-defined under equilibrium conditions (review in Clark and Fritz, 1997). For example, under complete isotopic equilibrium, $\mathrm{HCO}_{3}^{-}$is $\sim 7 \%$ enriched in ${ }^{13} \mathrm{C}$ compared to dissolved/aqueous $\mathrm{CO}_{2}$ at temperatures of $\sim 12{ }^{\circ} \mathrm{C}$. The $\delta^{13} \mathrm{C}_{\mathrm{DIC}}$ value is, therefore, very sensitive to changes in speciation with $\mathrm{pH}$ and can be used to understand the partitioning of $C$ in the system.

During all seasons, a decline in DIC concentrations associated with an increase in $\mathrm{pH}$ and $\delta^{13} \mathrm{C}_{\mathrm{DIC}}$ was detected as water flowed downstream from the mine portal. Plotting the $\delta^{13} C_{\text {DIC }}$ values against the total DIC concentrations yields strong correlation coefficients for all sampling seasons, with $R^{2}$ values of $0.96,0.92$ and 0.97 for December, February and July, respectively (Fig. 7). The slopes of the linear regression lines are very similar for all seasons. 


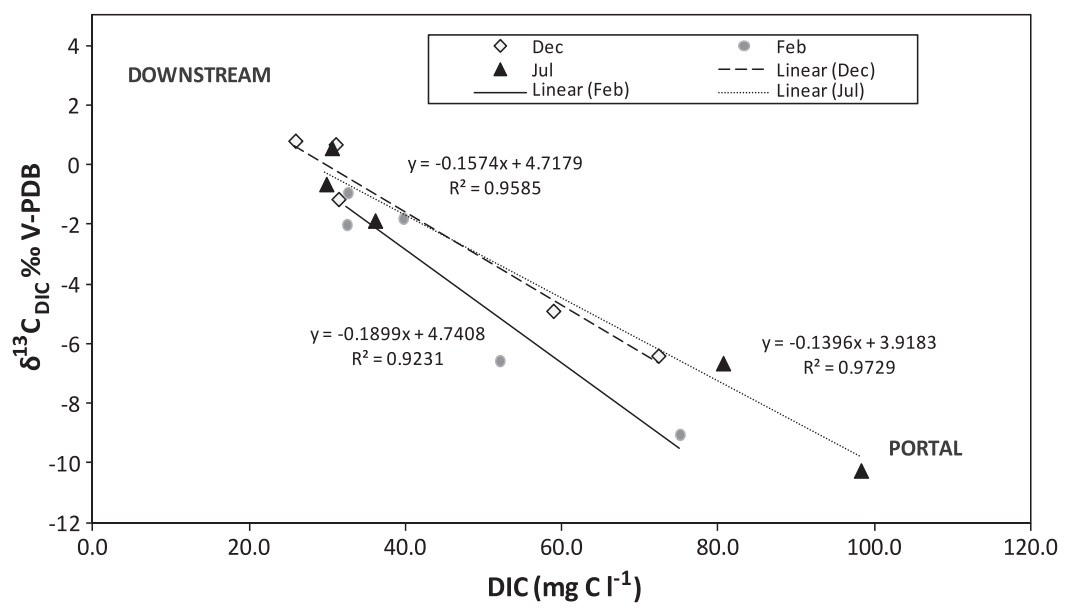

Fig. 7. The $\delta^{13} \mathrm{C}_{\mathrm{DIC}}$ and total DIC concentration trends from mine portal to downstream. Note the sharp rise in $\delta^{13} \mathrm{C}_{\mathrm{DIC}}$ as $\mathrm{CO}_{2}$ is lost via degassing.

Based on these slopes there was an increase of $0.16 \%, 0.19 \%$ and $0.14 \%$ in $\delta^{13} \mathrm{C}_{\text {DIC }}$ signatures per mg C/L decrease in DIC concentrations in December, February and July, respectively (Fig. 7). The two primary processes that can lead to a decline in total DIC concentrations are loss of dissolved $\mathrm{CO}_{2}$ due to degassing and the precipitation of carbonates.

$\mathrm{HCO}_{3}^{-} \rightarrow \mathrm{OH}^{-}+\mathrm{CO}_{2(\mathrm{~g})}$

$\mathrm{HCO}_{3}^{-}+\mathrm{Ca}^{2+} \rightarrow \mathrm{CaCO}_{3}+\mathrm{H}^{+}$

These processes have opposite effects on $\delta^{13} \mathrm{C}_{\mathrm{DIC}}$ and $\mathrm{pH}$. Outgassing of $\mathrm{CO}_{2}$ by reaction (6a) results in increases in $\delta^{13} \mathrm{C}_{\mathrm{DIC}}$ values and $\mathrm{pH}$, whereas carbonate precipitation results a decrease in $\delta^{13} C_{\mathrm{DIC}}$ and $\mathrm{pH}$ values.

Precipitation of carbonates is associated with a decline in the total $\delta^{13} C_{\text {DIC }}$ signature as ${ }^{13} \mathrm{C}$ is preferentially incorporated into the precipitating carbonate phase (Clark and Fritz, 1997). A decline in $\delta^{13} C_{\text {DIC }}$ signatures downstream from the portal or decreases in $\mathrm{pH}$ and dissolved $\mathrm{Ca}^{2+}$ concentrations were not seen (Table 1). Therefore, outgassing of $\mathrm{CO}_{2}$ is the likely primary cause of declining DIC concentrations.

Outgassing will result in an increase in the $\delta^{13} \mathrm{C}_{\mathrm{DIC}}$ of the water. At the study site, the progressive outgassing of $\mathrm{CO}_{2}$ downstream was accompanied by corresponding increases in the $\delta^{13} C_{\text {DIC }}$ signatures of the waters (Fig. 7). The measured dissolved $\mathrm{CO}_{2}$ concentrations declined from $156 \mathrm{mg} / \mathrm{L}$ to $11 \mathrm{mg} / \mathrm{L}$ in December, 136 to $8 \mathrm{mg} / \mathrm{L}$ in February, and 193 to $16 \mathrm{mg} / \mathrm{L}$ in July from the portal to the most distant downstream sample location. The $\delta^{13} C_{\text {DIC }}$ signatures showed an enrichment of $7.2 \%, 8.1 \%$ and $10.8 \%$ from the portal to the downstream site in December, February and July, respectively. However, the magnitude of $\delta^{13} \mathrm{C}_{\text {DIC }}$ enrichment was greater than expected based on the decrease in dissolved $\mathrm{CO}_{2}$ concentrations alone. It is hypothesized that this greater isotope enrichment is due to the kinetic isotope effect associated with $\mathrm{CO}_{2}$ degassing in a dynamic open system where chemical and isotopic equilibrium does not exist. A similar trend of $\delta^{13} C_{\text {DIC }}$ enrichment associated with $\mathrm{CO}_{2}$ degassing in streams has been reported by other workers (Mook et al., 1974; Marlier and O'Leary, 1984; Telmer and Veizer, 1999; Doctor et al., 2008; Fonyuy and Atekwana, 2008; Ali and Atekwana, 2009; Atekwana and Fonyuy, 2009).

\subsection{Strontium isotopes as tracer of subsurface processes}

Natural Sr isotope compositions have been used to identify geochemical processes related to the interaction of water from Appa- lachian coal mines with aquifer minerals and groundwater (Capo et al., 2001; Hamel et al., 2010; Chapman et al., 2012). If the DIC in groundwater is contributed by several sources, then conservative mixing between two end members may not adequately explain the $\delta^{13} C_{\text {DIC }}$ variations. In these cases, analysis of $\mathrm{Sr}$ isotopes can yield a critical check on the proportion of carbonate-derived DIC that was calculated from $C$ isotope mixing models.

The waters discharging from the mine portal are circumneutral (Table 1 ), but were likely acidic at their source due to the reactions described in Eqs. (4a) and (4b). Strontium isotope and geochemical data from mine water discharges associated with the nearby Irwin bituminous coal basin in southwestern Pennsylvania are consistent with the development of similar circumneutral, net alkaline waters as a result of carbonate mineral dissolution that is enhanced by subsurface cation exchange reactions between mine waters and clay minerals (Capo et al., 2001; Winters and Capo, 2004). Geochemical modeling suggests that this could be a significant process in other flooded underground coal mines in the region (Perry, 2001; Cravotta, 2008b). Clays and shale make up a substantial portion of overburden rocks that would come into contact with mine waters in the field area. The dominant clay minerals in the Pittsburgh Formation are kaolinite and illite, with up to $10 \%$ montmorillonite (McCulloch et al., 1974; O'Neill and Barnes, 1979). Eq. (7) describes the exchange equilibrium between two divalent cations, in which two $\mathrm{Na}^{+}$ions on exchange sites (EX) on clay mineral surfaces are replaced by one $\mathrm{Ca}^{2+}$ or $\mathrm{Mg}^{2+}$ ion:

$2 \mathrm{Na}-\mathrm{EX}+\mathrm{Ca}^{2}+\leftrightarrow \mathrm{Ca}-\mathrm{EX}+2 \mathrm{Na}^{+}$

As a result of this process, dissolved $\mathrm{Na}$ concentrations would increase, and the removal of $\mathrm{Ca}$ and $\mathrm{Mg}$ ions could further drive carbonate mineral dissolution, which would consequently increase alkalinity. The mine waters in this study are net alkaline and have elevated $\mathrm{Na}$ concentrations $(86-183 \mathrm{mg} / \mathrm{L}$ ) relative to nearby low pH mine discharges (19-27 mg/L Na; Capo et al., 2001). Calcium and $\mathrm{Mg}$ concentrations during the three sampling periods (Table 1) are within the range of bituminous coal mine discharges reported in Cravotta (2008a). Release of these ions during carbonate dissolution driven by cation exchange processes could compensate for Ca and Mg uptake by clay mineral surfaces (Capo et al., 2001; Perry, 2001).

The $\varepsilon_{\mathrm{Sr}}^{\mathrm{SW}}$ values for limestones overlying the Pittsburgh Coal that could contribute to alkalinity in the mine portal waters range from +21 to +33 , and values for acid-soluble calcareous clay and shale within the overburden strata average range from +93 to +291 (Table 2 ). The higher $\varepsilon_{\mathrm{Sr}}^{\mathrm{SW}}$ values are due to the addition of radiogenic ${ }^{87} \mathrm{Sr}$ resulting from the decay of $\mathrm{Rb}^{87}$. Rubidium, an alkali metal, is found in K-bearing clay minerals such as illite and montmorillon- 


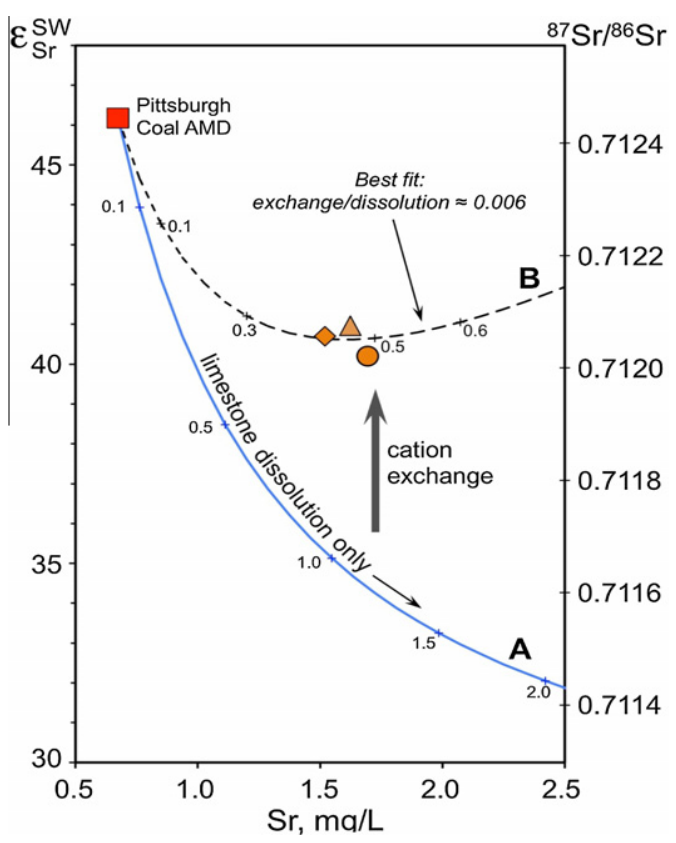

Fig. 8. Mineral dissolution and isotope exchange model for waters with an initial composition of Pittsburgh Coal AMD (filled square) interacting with limestone and shale as they move through the flooded mine. The lower curve (A) indicates the expected path for water interacting only with limestone, and the increments are grams of $\mathrm{CaCO}_{3}$ dissolved per liter of water. The upper dashed curve (B) shows a best-fit model for the mine portal waters in this study, where limestone dissolution is combined with cation exchange of water Sr for shale Sr. In this model, the rate of $\mathrm{Sr}$ exchange is equal to $\sim 0.6 \%$ of the rate at which $\mathrm{Sr}$ is added by limestone dissolution. Mine portal waters are shown as (o) December; $(\diamond)$ April; $(\Delta)$ July.

ite. Assuming an initial water composition similar to average low$\mathrm{pH}$ mine drainage originating from the Pittsburgh coal $\left(\varepsilon_{\mathrm{Sr}}^{\mathrm{SW}}=+46.2,0.68 \mathrm{ppm} \mathrm{Sr}\right.$; Chapman et al., 2012), and average values for overburden limestone $\left(\varepsilon_{\mathrm{Sr}}^{\mathrm{SW}}=+26.6,874 \mathrm{ppm}\right.$ Sr; Table 3), the mine portal waters do not fall on a mineral dissolution curve for pure mine water-limestone interaction (curve A, Fig. 8). However, exchange of mine water $\mathrm{Sr}$ with the more radiogenic $\mathrm{Sr}$ in the clay/shale overburden (average $\varepsilon_{\mathrm{Sr}}^{\mathrm{SW}}=+174.8$ ) has the effect of pushing the $\varepsilon_{\mathrm{Sr}}^{\mathrm{SW}}$ values higher with no net change in concentration ("cation exchange" vector in Fig. 8). A best-fit model combining limestone dissolution and cation exchange (curve B, Fig. 8) assumes that $\mathrm{Sr}$ in the mine water exchanges with the overburden clay/shale at about $0.6 \%$ of the rate that $\mathrm{Sr}$ is added from limestone dissolution. In this model, the mine water has dissolved $\sim 1 \mathrm{~g}$ $\mathrm{CaCO}_{3} / \mathrm{L}$ by the time it exits the portal, combined with a cumulative total exchange of $\sim 0.5 \%$ of the mine water $\mathrm{Sr}$ with clay/shale Sr. This mixing model suggests an addition of about $100 \mathrm{mg} \mathrm{C/L}$ of DIC to the water from limestone dissolution. These may be minimum values, because exchange of $\mathrm{Sr}^{2+}$ (and $\mathrm{Ca}^{2+}$ ) for $2 \mathrm{Na}^{+}$(Eq. (7)) will have the effect of lowering the $\mathrm{Sr}$ (and $\mathrm{Ca}$ ) concentration in the mine water, driving further limestone dissolution and requiring a greater extent of cation exchange to raise the $\varepsilon_{\mathrm{Sr}}^{\mathrm{SW}}$ values to those observed at the portal.

The lower $\varepsilon_{\mathrm{Sr}}^{\mathrm{SW}}$ in December $2010(+40.20 \pm 0.14)$ relative to July $2011(+40.96 \pm 0.13)$ suggests either a stronger influence from limestone dissolution in December, and/or a greater influence from mineral weathering or cation exchange in July. As discussed in Sections 4.1.1 and 4.2, the $\delta^{13} C_{\text {DIC }}$ data indicate that there was a greater contribution to DIC from carbonate dissolution in December 2010 than July 2011. Higher measured DIC concentrations in July suggest that it was augmented from other sources such as weathering. Increased $\mathrm{Ca}, \mathrm{Mg}, \mathrm{Fe}$ and $\mathrm{SO}_{4}$ concentrations in July are consistent with the dissolution of secondary sulfate minerals as discussed in Section 4.1.2.

\section{Conclusions}

Multiple stable isotopes $\left(\delta^{13} \mathrm{C}_{\mathrm{DIC}}, \delta^{34} \mathrm{SsO}_{4}, \delta^{18} \mathrm{O}_{\mathrm{SO}}\right.$, and $\left.\varepsilon_{\mathrm{Sr}}^{\mathrm{SW}}\right)$ were used to assess the sources and fate of DIC in the water draining from an abandoned bituminous coal mine drainage site. The $C$ in this groundwater originates from the oxidation of recent organic matter in the soils and from the dissolution of carbonate rocks along the flowpath. Generally, the organic and inorganic sources of $C$ have unique $\delta^{13} \mathrm{C}$ signatures. Using isotope mixing models, it can be inferred that the majority of the $C$ contribution to the total DIC is from dissolution of carbonate rocks, even though the percentage contribution appears to change seasonally. Sulfur and $\mathrm{O}$ isotopes of dissolved $\mathrm{SO}_{4}^{2-}$ in the mine were used to examine the contribution of $\mathrm{C}$ produced by oxidation of organic matter coupled with bacterial $\mathrm{SO}_{4}$ reduction. This process preferentially removes ${ }^{32} \mathrm{~S}$ and ${ }^{16} \mathrm{O}$, leaving behind a $\mathrm{SO}_{4}$ pool enriched in ${ }^{34} \mathrm{~S}$ and ${ }^{18} \mathrm{O}$. The higher $\delta^{34} \mathrm{SsO}_{4}$ and $\delta^{18} \mathrm{O}_{\mathrm{SO}}$ in mine waters at the study site, relative to other groundwater from nearby aquifers, indicate that these mine waters may have undergone some $\mathrm{SO}_{4}$ reduction along their flow-path. This is further supported by the presence of potential $\mathrm{SO}_{4}$-reducing bacteria. An increase in $\delta^{34} \mathrm{SsO}_{4}$ and $\delta^{18} \mathrm{O}_{\mathrm{SO} 4}$ values were also observed from December to July, accompanied by a decrease in $\delta^{13} C_{\text {DIC }}$. These trends suggest that fractional contribution from organic $C$ sources increases in summer due to increased biological productivity in soil and/or enhanced bacterial $\mathrm{SO}_{4}$ reduction activity within the mine pool. Strontium isotopic signatures are consistent with a greater contribution from limestone dissolution in December. Dissolved $\mathrm{CO}_{2}$ escapes to the atmosphere via outgassing after the mine water discharges to the surface and prior to entering the Youghiogheny River. This process is supported by the increase in $\delta^{13} C_{\text {DIC }}$ accompanied by decreased DIC concentrations and increased $\mathrm{pH}$ downstream from the portal.

\section{Acknowledgements}

As part of the National Energy Technology Laboratory's Regional University Alliance (NETL-RUA), a collaborative initiative of the NETL, this technical effort was performed under the RES Contract DE-FE0004000. The groundwater sampling was supported by USGS 104b Grant to S. Sharma. Partial support for this work was provided by the National Science Foundation's ADVANCE IT Program under Award HRD-1007978. This work was also partially supported by the DOE-Oak Ridge Institute for Science and Education Faculty Research Program to R. Capo. R. Capo thanks B. Stewart for comments and discussion. J. Moore, M. Mulder, M. Maley, K. Flannery and $\mathrm{M}$. Achille are thanked for help in sample processing and field work. The authors would like to thank Drs Charles Cravotta and Kinga Revesz for providing insightful comments that helped improve the manuscript.

\section{References}

Adams, J.P., 2012. The Geochemistry and $\mathrm{CO}_{2}$ Flux of Two Mine Discharges Allegheny County Pennsylvania. MS Thesis, West Virginia Univ.

Ali, H.N., Atekwana, E.A., 2009. Effect of progressive acidification on stable carbon isotopes of dissolved inorganic carbon in surface waters. Chem. Geol. 260, 102111.

Allison, J.D., Brown, D.S., Novo-Gradac, K., 1991. Minteqa2/Prodefa2, a Geochemical Assessment Model for Environmental Systems. Version 3.0 User's Manual. EPA/ 600/3-91/021 Athens, GA, 30605, EPA, USA.

Amiotte Suchet, P., Probst, P.J., Ludwig, W., 2003. Worldwide distribution of continental rock lithology: implications for the atmospheric/soil $\mathrm{CO}_{2}$ uptake by continental weathering and alkalinity river transport to the oceans. Global Biogeochem. Cycles 17 (2), 1038.

Aravena, R., Schiff, S.L., Trumbore, S.E., Dillion, P.J., Elgood, R., 1992. Evaluating dissolved inorganic carbon cycling in a forested lake watershed using carbon isotopes. Radiocarbon 34, 636-645.

Aravena, R., Harrison, S.M., Barker, J.F., Abercrombie, H., Rudolph, D., 2003. Origin of methane in the Elk Valley coal field, southeastern British Columbia, Canada. Chem. Geol. 195, 219-227. 
Atekwana, E.A., Fonyuy, E.W., 2009. Dissolved inorganic carbon concentrations an stable carbon isotopes ratios in streams polluted by variable amounts of acid mine drainage. J. Hydrol. 372, 136-148.

Botz, R., Pokojski, H.D., Schmitt, M., Thomm, M., 1996. Carbon isotope fractionation during bacterial methanogenesis by $\mathrm{CO}_{2}$ reduction. Org. Geochem. 25, 255-262.

Brady, B.C., Hornberger, R.J., Fleeger, G., 1998. Influence of geology on postmining water quality: Northern Appalachian Basin Pennsylvania. In: Brady, B.C., Smith, M.W., Schueck, J. (Eds.), Coal Mine Drainage Prediction and Pollution Prevention in Pennsylvania. Pennsylvania Department of Environmental Protection, Harrisburg, PA (Chapter 8).

Butman, D., Raymond, P.A., 2011. Significant efflux of carbon dioxide from streams and rivers in the United States. Nat. Geosci. 4, 839-842.

Cai, W.J., Guo, X.H., Chen, C.T.A., Dai, M.H., Zhang, L.J., Zhai, W.D., Lohrenz, S.E., Yin, K., Harrison, P.J., Wang, Y.C., 2008. A comparative overview of weathering intensity and $\mathrm{HCO}_{3}$ flux in the world's major rivers with emphasis on the Changjiang, Huanghe, Zhujiang (Pearl) and Mississippi Rivers. Cont. Shelf Res. 28, 1538-1549.

Calmels, D., Gaillardet, J., Brenot, A., France-Lanord, C., 2007. Sustained sulfide oxidation by physical erosion processes in the Mackenzie River basin: climatic perspectives. Geology 35, 1003-1006.

Capo, R.C., Winters, W.R., Weaver, T.J., Stafford, S.L., Hedin, R.S., Stewart, B.W., 2001 Hydrogeologic and geochemical evolution of deep mine discharges, Irwin Syncline, Pennsylvania. Proc. West Virginia Surface Mine Drainage Task Force Symp. 22, 144-153.

Chapman, E.C., Capo, R.C., Stewart, B.W., Hammack, R., Schroeder, K., Edenborn, H.M., 2012. Geochemical and strontium isotope characterization of produced waters from Marcellus Shale natural gas extraction. Environ. Sci. Technol. 46, 3545-3553.

Clark, I.D., Fritz, P., 1997. Environmental Isotopes in Hydrogeology. CRC Press, Boca Raton, FL.

Cole, J.J., Prairie, Y.T., Caraco, N.F., McDowell, W.H., Tranvik, L.J., Striegl, R.G., Duarte, C.M., Kortelainen, P., Downing, J.A., Middleburg, J., Melack, J., 2007. Plumbing the global carbon cycle: integrating inland waters into the terrestrial carbon budget. Ecosystems 10, 171-184

Cravotta III, C.A., 1994. Secondary iron-sulfate minerals as sources of sulfate and acidity: the geochemical evolution of acidic ground water at a reclaimed surface coal mine in Pennsylvania. In: Alpers, C.N., Blowes, D.W. (Eds.), Environmental Geochemistry of Sulfide Oxidation. American Chemical Society Symposium Series 550, pp. 345-364.

Cravotta III, C.A., 2008a. Dissolved metals and associated constituents in abandoned coal-mine discharges, Pennsylvania, USA. Part 2: geochemical controls on constituent concentrations. Appl. Geochem. 23, 203-226.

Cravotta III, C.A., 2008b. Dissolved metals and associated constituents in abandoned coal-mine discharges, Pennsylvania, USA. Part 1: constituent quantities and correlations. Appl. Geochem. 23, 166-202.

Daims, H., Bruhl, A., Amann, R., Schleifer, K.H., Wagner, M., 1999. The domainspecific probe EUB338 is insufficient for the detection of all Bacteria: development and evaluation of a more comprehensive probe set. Syst. Appl. Microbiol. 22, 434-444.

Deines, P., Langmuir, D., Harmon, R.S., 1974. Stable carbon isotope ratios and the existence of a gas phase in the evolution of carbonate groundwaters. Geochim. Cosmochim. Acta 38, 1147-1164.

Doctor, D.H., Kendall, C., Sebestyen, S.D., Shanley, J.B., Ohte, N., Boyer, E.W., 2008 Carbon isotope fractionation of dissolved inorganic carbon (DIC) due to outgassing of carbon dioxide from a headwater stream. Hydrol. Process. 22 2410-2423.

Ehrlich, H.L., Newman, D.K., 2009. Geomicrobiology. CRC Press, Taylor \& Francis Group, Boca Raton, FL.

Finlay, J.C., 2003. Controls of streamwater dissolved inorganic carbon dynamics in a forested watershed. Biogeochemistry 62, 231-252.

Fonyuy, E.W., Atekwana, E.A., 2008. Effects of acid mine drainage on dissolved inorganic carbon and stable isotopes in receiving streams. Appl. Geochem. 23 743-764.

Fritz, P., Basharmal, G.M., Drimmie, R.J., Ibsen, J., Qureshi, R.M., 1989. Oxygen isotope exchange between sulphate and water during bacterial reduction of sulphate. Chem. Geol.: Isotope Geosci. Section 79, 99-105.

Gammons, C.H., Duaime, T.E., Parker, S.R., Poulson, S.R., Kennelly, P., 2010 Geochemistry and stable isotope investigation of acid mine drainage associated with abandoned coal mines in central Montana, USA. Chem. Geol. 269, 100-112.

Glockner, F.O., Amann, R., Alfreider, A., Pernthaler, J., Psenner, R., Trebesius, K., Schleifer, K.H., 1996. An in situ hybridization protocol for detection and identification of planktonic bacteria. Syst. Appl. Microbiol. 19, 403-406.

Hamel, B.L., Stewart, B.W., Kim, A.G., 2010. Tracing the interaction of acid mine drainage with coal utilization byproducts in a grouted mine: strontium isotope study of the inactive Omega coal mine, West Virginia, USA. Appl. Geochem. 25, 212-223.

Hellings, L.K., Van Den Driessche, K., Baeyens, W., Keppens, E., Dehairs, F., 2000. Origin and fate of dissolved inorganic carbon in interstitial waters of two freshwater intertidal areas: a case study of the Scheldt Estuary, Belgium. Biogeochemistry 51, 141-160.

Holland, H.D., Turekian, K.K., 2011. Geochemistry of Earth Surface Systems: From the Treatise on Geochemistry. Elsevier Academic Press, Amsterdam.

Hornberger, R.J., Loop, C.M., Brady, K.B.C., Houtz, N.A., 2004. Geology of the Pennsylvania coal region. In: Coal ash Beneficial Use in Mine Reclamation and Mine Drainage Remediation in Pennsylvania. Pennsylvania Department of
Environmental Protection and Penn State Materials Research Institute, pp. 2052.

Kemp, A.L., Thode, H.G., 1968. The mechanism of the bacterial reduction of sulphate and of sulfite from isotope fractionation studies. Geochim. Cosmochim. Acta 32, 71-91.

Kirby, C.S., Dennis, A., Kahler, A., 2009. Aeration to degas $\mathrm{CO}_{2}$, increase $\mathrm{pH}$, and increase iron oxidation rates for efficient treatment of net alkaline mine drainage. Appl. Geochem. 24, 1175-1184.

Krouse, H.R., Mayer, B., 2000. Sulfur and oxygen isotopes in sulfate. In: Cook, P., Herczeg, A.L. (Eds.), Environmental Tracers in Subsurface Hydrology. Kluwer Academic Publishers, Norwell, MA

Lerman, A., Wu, L.L., Mackenzie, F.T., 2007. $\mathrm{CO}_{2}$ and $\mathrm{H}_{2} \mathrm{SO}_{4}$ consumption in weathering and material transport to the ocean, and their role in the global carbon balance. Mar. Chem. 106, 326-350.

Loy, A., Lehner, A., Lee, N., Adamczyk, J., Meier, H., Ernst, J., Schleifer, K.H., Wagner, M., 2002. Oligonucleotide microarray for 16S rRNA gene-based detection of all recognized lineages of sulfate-reducing prokaryotes in the environment. Appl. Environ. Microbiol. 68, 5064-5081.

Macalady, J.L., Lyon, E.H., Koffman, B., Albertson, L.K., Meyer, K., Galdenzi, S., Mariani, S., 2006. Dominant microbial populations in limestone-corroding stream biofilms, Frasassi cave system, Italy. Appl. Environ. Microbiol. 72, 55965609.

Marlier, J.F., O'Leary, M.H., 1984. Carbon kinetic isotope effects on the hydration of carbon dioxide and the dehydration of bicarbonate ion. J. Am. Chem. Soc. 106, 5054-5057.

Martini, A.M., Walter, L.M., Budai, J.M., Ku, T.C.W., Kaiser, C.J., Schoell, M., 1998. Genetic and temporal relations between formation waters and biogenic methane; Upper Devonian Antrim Shale, Michigan Basin, USA. Geochim. Cosmochim. Acta 62, 1699-1720.

Mayorga, E., Aufdenkampe, A.K., Masiello, C.A., Krusche, A.V., Hedges, J.I., Quay, P.D., 2005. Young organic matter as a source of carbon dioxide outgassing from Amazonia rivers. Nature 436, 538-541.

McCulloch, C.M., Diamond, W.P., Bench, B.M., Duel, M., 1974. Selected Geologic Factors Affecting Mining of the Pittsburgh Coal. U.S. Bureau of Mines Rept. Of Investigations 8093.

McIntosh, J.C., Martini, A.M., Petsch, S., Nüsslein, K., 2008. Biogeochemistry of the Forest City Basin coalbed methane play. Int. J. Coal Geol. 76, 111-118.

McLaughlin, J.F., Frost, C.D., Sharma, S., 2011. Geochemical analysis of Atlantic Rim water, Carbon County, Wyoming: New applications for characterizing coal bed natural gas reservoirs. Am. Assoc. Petrol. Geolog. Bull. 95, 191-217.

Metzgar, B., 2003. The Great Allegheny Passage Companion: Guide to History \& Heritage Along the Trail. Local History Company, Pittsburgh, PA.

Mook, W.G., Tan, F.C., 1991. Stable carbon isotopes in rivers and estuaries. In: Degens, E., Kempe, S., Richey, J. (Eds.), Biogeochemistry of Major World Rivers. John Wiley and Sons, New York, pp. 245-264.

Mook, W.G., Bommerson, J.C., Staverman, W.H., 1974. Carbon isotope fractionation between dissolved bicarbonate and gaseous carbon dioxide. Earth Planet. Sci. Lett. 22, 169-176.

Mulder, M.L., 2012. Ambient Geochemical and Isotopic Variations in Groundwaters Across an Area of Accelerating Shale Gas Development. West Virginia Univ., MS Thesis.

O’Neill, B.J., Barnes, J.H., 1979. Properties and Uses of Shales and Clays, Southwestern Pennsylvania, PA. Dept. of Env. Res., Harrisburg, PA.

Perry, E.P., 2001. Modeling rock-water interactions in flooded underground coal mines, northern Appalachian Basin. Geochem.: Explor. Environ., Anal. 1, 61-70.

Pierre, C., 1989. Sedimentation and diagenesis in restricted marine basins. In: Fritz, P., Fontes, J.Ch. (Eds.), Handbook of Environmental Isotopes. Elsevier, pp. 257315.

Puls, R.W., Barcelona, M.J., 1996. Low-Flow (Minimal Drawdown) Ground-Water Sampling Procedures. In: Ground Water Issue. United States Environmental Protection Agency, EPA/540/S-95/504.

Quay, P., King, S., Wilbur, D., Wofsy, S., Richey, J., $1989 .{ }^{13} \mathrm{C} /{ }^{12} \mathrm{C}$ of atmospheric $\mathrm{CO}_{2}$ in the Amazon Basin: forest and river sources. J. Geophys. Res. 94, 18327-18336.

Richey, J.E., Melack, J.M., Aufdenkampe, A.K., Ballester, V.M., Hess, L.L., 2002. Outgassing from Amazonian rivers and wetlands as a large tropical source of $\mathrm{CO}_{2}$. Nature 416, 617-620.

Rose, A.W., Cravotta III, C.A., 1998. Geochemistry of coal mine drainage. In: Brady, K.B.C., Smith, M.W., Schueck, J. (Eds.), Coal Mine Drainage Prediction and Pollution Prevention in Pennsylvania. Pennsylvania Department of, Environmental Protection, pp. 1-22.

Scott, A.R., Kaiser, W.R., Ayers Jr., W.B., 1994. Thermogenic and secondary biogenic gases, San Juan Basin, Colorado and New Mexico: implications for coalbed gas producibility. Am. Assoc. Petrol. Geol. Bull. 78, 1186-1209.

Seal II, R.R., 2003. Stable-isotope geochemistry of mine waters and related solids. In: Jambor, J.L., Blowes, D.W., Ritchie, A.I.M. (Eds.), Environmental Aspects of Mine Wastes. Mineralogical Association of Canada Short Course 31, pp. 303-334.

Seal II, R.R., Cravotta III, C.A., 2006. Stable isotope characteristics of abandoned coal mine discharges, Pennsylvania. In: Geol. Soc. Am. Ann. Meetingl, October 2006: Abstracts with Programs, Abstract 134-5.

Sharma, S., Baggett, J.K., 2011. Application of carbon isotopes to detect seepage out of coalbed natural gas produced water impoundments. Appl. Geochem. 26, 1423-1432.

Sharma, S., Frost, C., 2008. An innovative approach for tracing coalbed natural gas co-produced water using stable isotopes of carbon and hydrogen. Groundwater $46,329-334$. 
Simpkins, W.W., Parkin, T.B., 1993. Hydrogeology and redox geochemistry of $\mathrm{CH}_{4}$ in a late Wisconsinian till and loess sequence in central Iowa. Water Resour. Res. 29, 3643-3657.

Taylor, B.E., Wheeler, M.C., Nordstrom, D.K., 1984. Isotope composition of sulphate in acid mine drainage as measure of bacterial oxidation. Nature 308, 538-541.

Telmer, K., Veizer, J., 1999. Carbon fluxes, pCO2 and substrate weathering in a large northern river basin, Canada: carbon isotope perspectives. Chem. Geol. 159, 6186.

Toran, L., Harris, R.F., 1989. Interpretation of sulphur and oxygen isotopes in biological and abiological sulfide oxidation. Geochim. Cosmochim. Acta 53, 2341-2348.

U.S. Environmental Protection Agency (EPA), 2008. Mining Operations as Nonpoint Source Pollution. EPA, Washington, DC. <http://www.epa.gov/reg3wapd/nps/ mining.html>

Van Donkelaar, C.V., Hutcheon, I.E., Krouse, H.R., 1995. $\delta^{34} \mathrm{~S}, \delta^{18} \mathrm{O}, \delta \mathrm{D}$ in shallow groundwater: tracing anthropogenic sulfate and accompanying groundwater/ rock Interactions. Water Air Soil Pollut. 79, 279-298.

Van Everdingen, H.R., Krouse, H.R., 1985. Isotope composition of sulphates generated by bacterial and biological oxidation. Nature 315, 395-396.
Vesper, D.J., Edenborn, H.M., 2012. Determination of free $\mathrm{CO}_{2}$ in emergent groundwaters using a commercial beverage carbonation meter. Journal of Hydrology 438-439, 148-155

Vesper, D.J., Smilley, M.J., 2010. Attenuation and diel cycling of coal-mine drainage constituents in a passive treatment wetland: a case study from Lambert Run, West Virginia, USA. Appl. Geochem. 25, 795-808.

Whiticar, M.J., 1999. Carbon and hydrogen isotope systematic of bacterial formation and oxidation of methane. Chem. Geol. 161, 291-314.

Winters, W.R., Capo, R.C., 2004. Groundwater flow parameterization of an Appalachian coal mine complex. Ground Water 42, 700-710.

Yao, G.R., Gao, Q.Z., Wang, Z.G., Huang, X.K., He, T., Zhang, Y.L., Jiao, S.L., Ding, J., 2007. Dynamics of $\mathrm{CO}_{2}$ partial pressure and $\mathrm{CO}_{2}$ outgassing in the lower reaches of the Xijiang River, a subtropical monsoon river in China. Sci. Total Environ. 376, 255-266.

Zeng, F.W., Masiello, C.A., 2010. Sources of $\mathrm{CO}_{2}$ evasion from two subtropical rivers in North America. Biogeochemistry 100, 211-225.

Zhang, S., Lu, X.X., Sun, H., Han, J., Higgitt, D.L., 2009. Major ion chemistry and dissolved inorganic carbon cycling in a human-disturbed mountainous river (the Luodingjiang River) of the Zhujiang (Pearl River), China. Sci. Total Environ. 407, 2798-2807. 